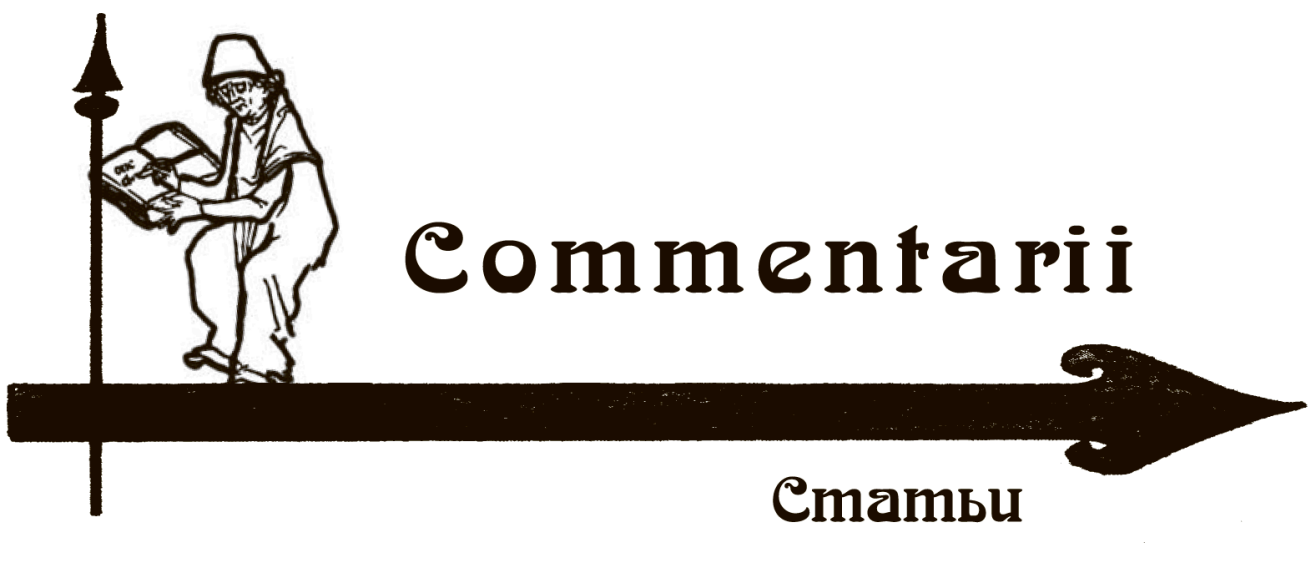

СЛАВЯНСКАЯ ИДЕНТИЧНОСТЬ В СРЕДНИЕ ВЕКА

УДК 94(47+57)(=16); ББК Т3(49=Сл)4; DOI https://doi.org/10.21638/11701/spbu19.2018.101

M. Homza

\title{
A FEW WORDS ABOUT THE IDENTITY OF THE SLAVS, YESTERDAY, TODAY AND TOMORROW
}

Through its cultural heritage a society becomes visible to itself and to others ${ }^{1}$

Jan Assman

Nobody else in Europe, besides the Slavs, has managed to create the concept of selfidentification with its starting point and centre of gravity in their own name. This historical phenomenon is hard to explain and thus beyond the ability to reflect of many, especially

${ }^{1}$ Assman J. New German Critique. Collective Memory and Cultural Identity // Cultural History / Cultural Studies. 1995. Vol. 65. P. 133.

(C) Homza M., 2018 
among non-Slavic thinkers ${ }^{2}$. The issue, however, is not impossible to solve, although it may seem so at first sight, or is presented to be so.

Anyone wanting to describe the matter in all its complexity would need more space than just an article. The whole set of historical, theological, cultural, sociological, economic and legal processes which led to the present status needs an explanation. This certainly surpasses the abilities and capabilities of one single scholar. What I aim to do at this point is to sketch the causes which led to the unusual success of the Slavic identity ${ }^{3}$ in several points.

As it has already been said, it is a very unusual phenomenon in the history of mankind. The aim of this article is to explain it using appropriate modern terminology understandable to the present reader. Its medieval origins not only form the foundation of the present-day understanding of Slavic identity, but they also transcend to the present. Some digressions from nineteenth-century philosophy and historiography cannot be avoided. Neither will I avoid summarising the results of some contemporary thinkers who have dealt with the dissemination of the Slavic identity.

It is necessary to get rid of various rests of the so-called «professional» terminology, which in many cases does not touch the essence of the researched problem at all. The system of these so-called expert terms, word constructions and phrases, does not reflect the historical reality in the slightest, although this is precisely what they claim to do. However, it «magically» creates reality. On the other hand, the meta-language has been rooted and used in scholarly discourse into such extent that it has become the subject of teaching at primary and secondary schools and have become part of the so-called «spiritual facts» or social consciousness in various countries of Europe and around the world, i.e. a kind of self-evident element, which does not need any further consideration.

One of these unlucky phrases, «Slavic antiquities», was made up by Pavol Jozef Šafárik in the first half of the $19^{\text {th }}$ century ${ }^{4}$ following some older German models. In the second half of the $20^{\text {th }}$ century, the term was substituted with a modern, equally «magic» word, which forms part of the «magical (old-)Slavic reality» until today: «the ethnogenesis of the Slavs» 5 .

${ }^{2}$ Pohl $W$. Początki Słowian: Kilka spostrzeżeń historycznych // Nie-Słowianie o początkach Słowian / Ed. by P. Urbańczyk. Poznań, 2006. P. 11-27, here other authors as well.

${ }^{3}$ I consider the term «identity» as a key and starting point of my considerations in many respects, see: Identität / Ed. by O. Marquard and K. Stierle. München, 1996. See also a collection of more recent works: From Roman Provinces to Medieval Kingdoms / Ed. by Th. F. X. Noble. London, 2006, especially Part I: Geary P. J. The Crisis of European Identity Barbarian Ethnicity and Identity // Ibid. P. 27-34, Wolfram H. Origo et religio: Ethnic traditions and literature in early medieval texts // Ibid. P. 57-74; Pohl W. Telling the difference: Signs of ethnic identity // Ibid. P. 99-138. - In many respects a groundbreaking text touching on the identity of Slavs is Brather S. Ethnische Interpretationen in der frühgeschichtlichen Archäologie: Geschichte, Grundlagen und Alternativen. Berlin; New York, 2004. See especially chapter «Ethnische Identitäten und kulturelles Gedächtnis» (Ibid. P. 104-117).

${ }^{4}$ It concerns especially the first part of Slovanské starožitnosti (Slavic antiquities), which described the «Slavic» history from the times of Herodotos, i.e. 456 BC. See: Šafárik P. J. Slovanské starožitnosti. Praha, 1837. To be sure, neither at the time nor today was it possible without serious methodological problems. See also: Podolan P. Aspekty slovenskej historiografie generácie Jána Kollára a Pavla Jozefa Šafárika // FH. 2007. Vol. 1. P. 1-13.

${ }^{5}$ On the term ethnogenesis, see: Wolfram $H$. Terminologisches // Nomen und Fraternitas: Festschrift für Dieter Geuenich zum 65. Geburtstag / Ed. by U. Ludwig and Th. Schilp. Berlin; New York, 2008. P. 787-790. 
Almost nobody seems to mind that the technical term etnos is so difficult to grasp that it can be applied to contemporary modern European nations just as to comparably little known communities somewhere in the Amazonian forest or in Papua New Guinea. If one wants to search for the original use of etnos, supposedly an emotionally empty term, one should turn to the place where they most wanted to create a new egalitarian civic society free of the residues of history before WWII, i.e. Soviet Russia. The term etnos was introduced to academic study by Sergey Michaylovich Shirokogorov (Сергей Михайлович Широкогоров) at the end of the 1920s. The author himself, however, had no idea that the term would have such a great career in another field: in the tenacious and at the same time meaningless struggle concerning the uncomfortable effects of the collapse of the ancient Roman Empire, together with terms like gens - tribe, but especially natio - nation ${ }^{6}$. Moreover, neither late Roman informers nor the subsequent medieval written tradition knew the term etnos at all. Instead, non-Roman communities with special identities are most often called gentes, populi, or simply nationes. Medievalists today need to understand the contemporary term in its contemporary sense, and retell it in a language understandable to present-day readers. Inventing new terms and applying them to historical reality does not always work out. Although I have used the term etnos myself until recently, now I do not consider it clear enough to describe the processes related to the appearance of the Slavs on the stage of history.

The situation with the second constituent of the technical term ethnogenesis is even worse. The word genesis, being the name of the key book of the Old Testament, has a strong religious connotation. It is basically translated as «origin», but also as «development». The process is always set at a certain time (it can be even cosmological, but always in time) and space (which has, at least, cultural and religious connotations, too). Achieving a goal also means starting a new, rather clear system of relations, a paradigm of a new quality. In the case of the Slavs, however, there is practically no information about such ethnogenetic process, especially its starting point. We may be misled by learned Jordanes who says that in the past the Slavs used to call themselves Veneti ${ }^{7}$. If this were true, however, we would have certainly found a source proving this somewhere in the oldest history of the Slavs. However, there is no such self-identifying narrative among the Slavic authors. Nevertheless, it is known that Western Slavs were called Wenden by their German-speaking neighbours until recently. This is then an exonymum for Slavs, i.e. the name under which they were known and described by their Gothic, and later Gepid neighbours. It was also from there that this name found its way into the archaic usage of the German language. Jordanes was most probably of Gothic origin himself (most probably even an Amal/Amaling partially). Thus, his name for the Slavs is not surprising. It builds on contemporary reflection of an intellectual who knew the political situation on the other side of the Danube. The problem with the narrative is, however, that

\footnotetext{
${ }^{6}$ On the term «etnos», see also: Wolfram $H$. Terminologisches. See also: Curta F. The Making of the Slavs: History and Archeology of the Lower Danube Region, c. 500-700. Cambridge, 2001. P. 14-23.

${ }^{7}$ Venethi (...) «quorum nomina licet nunc per varias familias et loca mutentur, principaltier tamen Sclaveni et Antes nominantur» (Iordanis. Getica V, 34) (MGH. Auctores antiquissimi / Rec. Th. Mommsen. Vol. 5. Berolini, 1882. P. 62-63). In another place (XXIII, 119) the same author mentions the name Veneti not as a generative term, that is, from which Slavs and Anti developed, but as a term equal with Slavs and Anti, although he admits that Veneti were the first whom Gothic king Hermanrich subordinated to himself (Ibid. P. 88-89).
} 
earlier than that, some ancient writers (Ptolemaios, Tacitus) mention another community with a similar name. It is hard to claim, however, that the ancient Veneti, who according to the mentioned authorities lived around the Vistula River up to present Gdansk as well as in northeastern Italy around Venice (which even has its name after them), are automatically identical with the later Slavs. Almost a classical example of this is the work by Ján Kollár Staroitalia slavjanská: aneb objevy a dỉkazy živlů slavských v zemepisu, v dejinách a v bájesloví (Vienna 1853). It is impossible to speak about the Slavs before the apparition of this term - that is, before a specific group of skilled military men in the mid and lower Danube started to identify themselves as Slavs, at least without falling into daring conjectures.

Despite this, the «scholarly» narrative has been doing so continuously. The advocates of this approach perhaps do not even realise that they mechanically proceed in the same way as the first chronicler of old Rus' - Nestor the Chronicler, or the unknown author of the relevant part of the Russian Primary Chronicle. For him, anchoring the Slavs in the Old Testament biblical tradition was one of the standard literary ways of legitimising the contemporary cultural, and especially religious, situation of Slavdom in Rus's. Other European narrators at different times proceeded in the same way and explained the causes of the present condition with the help of events described in the Old Testament and by ancient authors, especially after the fall of Troy (as Virgil did for the Romans) ${ }^{9}$.

It is hard to establish the motivation of all those who locate the "prenatal state" of Slavdom outside the scope of contemporary Roman informers in the dark corners of impenetrable Scythia, or let say, in the best case, to the Pripyat Swamps (Pinsk Marshes) in present-day Belarus $^{10}$, i.e. at the edge of or even beyond the contemporary world, to the deep unconscious of Europe ${ }^{11}$. They most often refer to the alleged geographical optics of Jordanes. He not only connected the Wends (called so by Goths) with the ancient Veneti (using the same formula, he connected the Goths with Gets/Getae), but he also placed them at the basin of the river Vistula. On the other hand, he also rather precisely described the actual location of the Slavs around the mid $6^{\text {th }}$ century, where (accidentally?) his contemporaries John of Ephesos, Prokopios of Caesarea and other later authors also happen to find them. The Slavic cultural tradition itself, written or described by Nestor the Chronicler, remembers them at the same place, i.e.

${ }^{8}$ The «Russian Primary Chronicle», or also «The Tale of Bygone Years» (Povest' vremennych liet) has numerous editions, translations and commentaries until present days. I will draw on the classical edition: Повесть временных лет / Подготовка текста, перевод, статьи и коммент. Д. С. Лихачева; под ред. В. П. Адриановой-Перетц. 3-е изд. СПб., 2007 (hereafter ПВЛ). Its introductory part, known also under the title «Tale of the settlement of Slavs on the Danube and invasion of Hungarians», presents the Slavs as descendants of Old Testament Japhet, son of Noah, the fall of the Babel tower, confusion of languages in the land of Senar. Afterwards, Nestor informs us that they settled on the Danube, in the place where the Hungarian and Bulgarian lands are today.

${ }^{9}$ Brown E. A. R. Myths Chasing Myth: The Legend of the Trojan Origin of the French and its dismantling // The Man of Many Devices, who Wandered full Many Ways...: Festschrift in Honor of János M. Bak / Ed. by B. Nagy and M. Sebők. Budapest, 1999. P. 613-633.

${ }^{10} \mathrm{On}$ the margin, I am bound to say that the swamps were overcome with great difficulties after several months of preparation by an ingenious general (and future marshall) Konstantin K. Rokossovskij while realizing the operation Bagration during the Great Patriotic War.

${ }^{11}$ See review of Máčala P. Etnogenéza Slovanov v archeológii. Košice, 1995, by Ďurina L'. Malá knižná reminiscencia // Proglas. 1999. Vol. 10. No. 2. P. 11-14. 
on the mid or lower Danube, in the former Roman provinces of Dacia, Pannonia and later (in Nestor) in Noricum as well.

«Blaming» Jordanes is understandable in the case of western scholars: they often see the apparition of the Slavs as an «obscure», i.e. doubtful process ${ }^{12}$. If they talk about the Slavs at all, that is. For them, the Slavs remain until today, with very few exceptions, an incomprehensible, irrational entity and, therefore, they unconsciously (?) try to push it, at least mentally, as far away from their «understandable» horizon as possible ${ }^{13}$. From this viewpoint, a muddy area in the middle of nowhere is an ideal place for the Slavic «ethnogenesis» for many reasons. Much more difficult to understand is, however, how it is possible that some Slavic scientists accept this nonsense, too ${ }^{14}$.

The ancient homeland (Urheimat) of the Slavs is another topic, on which scholars keep writing and discussing endlessly. Nevertheless, this term cannot and should not be used without limits, as it is often the case today. Those who do often do not realise that the first to describe «the cradle» of the Slavs was Nestor the Chronicler or his source: «Over a long period the Slavs settled beside the Danube, where the Hungarian and Bulgarian lands now lie» ${ }^{15}$. Thus, this chronicler we know as Nestor, and after him other Slavic medieval chroniclers as well ${ }^{16}$, have the «ancient homeland» of the Slavs in the Danube basin. The anonymous author of this historical construction about the origin of the Slavs uses, however, more precise delimitations than some scholars do today. He calls the «country of origin», or rather the place of formation and subsequent division - «The Egypt of the Slavs» - as «the land of the Slavs» - земля словеньска, geographically delimited by the three Roman provinces of Dacia, Pannonia, and Noricum ${ }^{17}$. The unknown author of these lines adapted the literary form of the Old Testament story of the sons of patriarch Jacob and used it to describe the «origin» of the Slavs, connecting it with the older oral tradition of the «Slavic memory». Most certainly, he did so on purpose and consciously, unlike most contemporary scholars, who would not understand that they have been (mis-)led in their theses about the «ancient homeland» of the Slavs by a biblical scheme - the matrix about the origin of the chosen Jewish people, who formed from the descendants of Jacob in their «ancient homeland» (Egypt) and then wandered for 40 years to their promised land of Israel $^{18}$.

${ }^{12}$ Pohl W. Die Awaren: ein Steppenvolk im Mitteleuropa, 567-822 n. Chr. München, 2002. P. 94. ${ }^{13}$ See, for example, the European project and subsequent series - Transformation of the Roman World (1993-1997), including 18 edited collected volumes with more than 100 participants from 20 countries. See: http://www.brill.com/publications/transformation-roman-world. As far as the questions concerning the apparition of Slavs on the historical scene and their role in the transformation of the post-Roman world are concerned, the volumes do not contain almost any relevant information.

${ }^{14}$ For all works, let me mention Ván̆a Z. Svět dávných Slovanů. Praha, 1983.

${ }^{15}$ The Russian Primary Chronicle: Laurentian Text / Transl. and ed. by S. H. Cross and O. P. Sherbowitz-Wetzor. Cambridge (Mass.), 1953. Р. 52-53. «По мнозъхъ же времяньх сьли суть словьни по Дунаеви, гдђ есть ныне Угорьска земля и Болгарьска» (ПВЛ. С. 8).

${ }^{16}$ Mesiarkin A. Examining the Slavic Identity in the Middle Ages: Perception of Common Sense of Slavic Community in Polish and Bohemian Medieval Chronicles // Studia Ceranea. 2013. Vol. 3. P. 83-100.

${ }^{17}$ Avenarius A. Začiatky Slovanov na strednom Dunaji: Autochtonistická teória vo svetle súčasného bádania // HČ. 1992. Vol. 40. No. 1. P. 1-16.

${ }^{18}$ Smith A. D. Myths and Memories of the Nation. Oxford, 1999. P. 84. 
Likewise, the term «ancient Slavic (linguistic) unity» is nothing else than a more sophisticated variant of the expression «ancient homeland». It implies, however, a certain ideal state, in which all ancestors of the future Slavs, at an undefined time, shared a common space, which is neither more closely defined nor identifiable. In this space, naturally, they communicated in an ideal, single and common - «ancient Slavic» language. However, this unity (like the unity of any community, starting from a family as the basic biosocial unit of mankind) is the outcome of abstraction and imagination rather than a potentially real historical condition.

When talking and writing about the Slavs and the mysterious way their identity spread, you need to accept — and refute — some of the scholarly terms and reasoning processes that have become so popular in this discussion, which has been going on among scholars in Europe and worldwide at least since the times of Pavol Jozef Šafárik († 1861), the founder of Slavic studies. However, it also implies applying the most important results of the specialised discourse on the origin and evolution of the identities of male military communities onto the Slavic people. These political subjects appeared in the European Barbaricum, or at least became known to contemporary annalists, at the time the Roman Empire faced its crisis in the $4^{\text {th }}$ and $5^{\text {th }}$ centuries AD. To join this discussion you also need to summarise, give elementary consideration to and even dispute its major outputs.

The idea that the Slavs represent a certain «ethnic» or linguistic group among the inhabitants of Eurasia is one of the most misleading theses in this question. There is simply need to get rid of this this idea once and for all. As this article aims to demonstrate, the cultural identity of all those who today talk and write about themselves as Slavs transcends by far the so very narrow definition of an "ethnic" group (nation). The Slavic identity is not bound up with language. Indeed, not all contemporary Poles, Czechs, Croatians or Bulgarians identify themselves as Slavs despite the fact that their languages are really closely related. On the contrary, a number of Slavs, e.g. in the United States, have completely forgotten their original language but are not willing to give up their Slavic identity.

In my opinion, most contemporary European nations, which besides their own specific denomination have accepted the name Slav or Slavic - such as the Croatians, the Russians and the Poles, but also others, were not originally Slavs. Indeed, the members of these nations cannot claim to be direct descendants of the first, historically known Slavs, i.e. that their identity has always been Slavic at the same time. They simply «became» Slavs at a specific point of their history under certain conditions. Their Slavic identity is, at least in my opinion, secondary. Unlike them, Slovaks and Slovenes have only one identity each, although their personal name could have changed in history.

The Slavs are not a mere group of several different, more or less related languages, like those European nations that form the Germanic language group (the Norwegians, the Danes, the English, and the Germans). The Slavs have either nothing or very little in common with the identities that emerged from the ruins of the Roman Empire (the Spanish, the Portuguese, the Italians, the French). Neither are they the result of a single common political unit (state) like the Romans or the Chinese. Their identity is not the mere result of historical circumstances, like it is the case of the Swiss, the Dutch and the Luxemburgians. The Slavs are connected by far stronger bonds than the above mentioned ones, the most important of which is traditionally considered to be the still often overrated linguistic proximity. 
In my opinion, the best attempt to approach the problem of Slavdom and Slavic identity in a methodological way was Ján Kollár's († 1852) in the first half of the $19^{\text {th }}$ century. In his opinion, the willingness to identify oneself with the name Slav is above all the result of an attractive cultural concept, which he characteristically calls Slavic «literary reciprocity» ${ }^{19}$. With his understanding of the question of (Slavic) identity as a specific, in history unparalleled cultural concept (represented mainly in literary form), Ján Kollár preceded by more than a century all historicising sociologists, or sociologising archeologists who have tried to describe and explain in scholarly terms the existence of «Slavdom», which has become part of the «concert» of the most influential social identities of the contemporary world. However, it is a well known fact that the basis of every social identity is the formation of a collective memory of the community.

What Ján Kollár defined in his renowned work «On the Literary Reciprocity Between the Various Tribes and Dialects of the Slavic Nation» (Über die literarische Wechselseitigkeit zwischen den verschiedenen Stämmen und Mundarten der slawischen Nation, 1837) was the desired rather than the actual situation of the common «cultural consciousness» of all those who in the first half of the $19^{\text {th }}$ century were or in his opinion should be willing to add to their tribal (national) name the distinction «Slavic», which has withstood the test of time and is coated in glory.

Unlike Kollár, I think that «being Slav» is not a static condition identical in the prehistory of mankind («Slavic antiquities») and today, but rather a dynamic condition with its own history and, therefore, has gone through specific historical periods with their own particular features. The ideal state of Slavdom appears every day anew, it exists in the present, was different in the past and will be different in the future. Thus, «being Slav» is above all a dynamic and constantly evolving status. The number of Slavs and, thus, the quality - i.e. the extent and intensity - of their self-identification has varied in history since its origin, thriving and declining according to the current political demand. Indeed, the number of Slavs appears to have reached its peak after the victorious WWII and the revival of the concept of neoslavism by Josif V. Stalin in the Soviet Union. Moreover, «being Slav» also depends and has always depended on the context. It is not the same to identify oneself with Slavdom in present-day Russia as it is in Slovakia, Slovenia or, for instance, in Lusatia.

Before talking about the «Slavic cultural memory» — which is considered to be the material from which the Slavic identity has been and is still built up - you need to separate «the wheat from the chaff» in an almost biblical way and go back to the moment its earliest foundations were defined. It is necessary to return to the times when the new non-Roman political subjects that played important - if not decisive — roles in later European history originated and defined themselves in the Barbaricum, i.e. in the shadow of the weakening Roman Empire and its ruins. In connection with the fall of any legal environment related to the everyday life of the

${ }_{19}$ «But literary reciprocity is the common participation of all national branches on the spiritual fruit of their own nation...» («Ale literárna vzájomnost’ je spoločná účast' všetkých národných vetiev na duševných plodoch vlastného národa..») (Kolár J. O Literárnej vzájomnosti medzi rozličnými kmeňmi a nárečiami slovanského národa (Über die literarische Wechselseitigkeit zwischen den verschiedenen Stämmen und Mundarten der slawischen Nation) // http://zlatyfond. sme.sk/dielo/307/Kollar_O-literarnej-vzajomnosti/2 /§ 2 (last accessed: 01.05.2018). More on the work and analysis of Ján Kollár, see: Podolan P. Odkaz Jána Kollára slovenskej historiografii // Historia nova. 2012. Vol. 5. P. 43-51. 
Roman Empire, the origin and duration of these subjects depended above all on their military power and their ability to effectively push through their will among their neighbours. This was usually achieved by establishing some mutually advantageous relations, which consisted of an arrangement according to which the settled (agrarian) population used the armed protection of «its» male military community against other similar peoples. This protection, of course, was not for free but for a charge called tributum pacis, i.e. peace fee. This archetypal kind of social contract has existed since times immemorial. A good example to illustrate this practice to present-day readers can be found in the popular movie The Magnificent Seven, in which the inhabitants of a forgotten Mexican village hire a group of killers in an attempt to put an end to the unbearable «taxation» they had been forced to pay to a band of robbers. There is no doubt that this kind of mutually advantageous interaction was common practice in areas that did not know the Roman law.

It is the countries of the former Soviet bloc that have the worst experience with the spontaneous rise of semi-military male hierarchical groups. These modern-day retinues appeared as parallel power structures immediately after the collapse of the bloc at the end of the 1980s and during the 1990s. They aimed to take over the reins from a weakening government structure, which was no longer able to guarantee the enforcement of the law. Everyday territorial conflicts among these groups accompanied by brutal fights and the collection of the modern tributum pacis (protection racket) — often with the silent agreement of the authorities - is a sad experience most citizens in the post-Soviet area would rather forget. Many people will define the features of these Männerbunde based on their own experience: extravagant fashion, expensive weapons, foreign cars, beautiful female companions, rich ritual banquets, etc. Many will also remember the distinctive names these groupings went by. Most of these men, trained fighters and killers, came from declining army and top sport milieux... A similar situation occurred over 1500 years ago. The territories north of the Danube saw military groups sprung up like mushrooms after the rain in the void left by the Roman authorities. In the territories of the former Roman provinces of Dacia, Pannonia and Noricum, though, the interaction between «the protectors» and «the protected» went beyond paying the peace fee. Indeed, the protected population eventually took over the identification patterns of the «tax collectors». This is very likely to have been the beginning of the story of the successful dissemination of the name of the male military community of the Slavs among other post-Roman peoples north of the Danube in the second half of the $5^{\text {th }}$ century ${ }^{20}$.

The present-day scholarly discourse on the early medieval identities of male communities (Männerbund) ${ }^{21}$ among non-Roman political subjects beyond the borders of the late (eastern) Roman Empire - which for working purposes are called tribes or gentes in Latin fundamentally agrees on the fact that it was not the biological bond (blood relation), the language, some extravagant male fashion, or the intentional shaping of the group's material culture following some pre-defined «ethnic» models, but rather the quality and attractiveness of their own cultural memory as well as the means and effectiveness this memory was spread

${ }^{20}$ The theory of the first social contract between «Slavs» and the population of post-Roman provinces of Pannonia and Dacia is developed in Homza M. Stredná Európa. Vol. 1: Na začiatku stredoveku. Bratislava, 2014. P. 34-35. - It was tentatively called with the help of 2 originally Gothic words, «theory of sword for bread», that is, military protection of the population for tax in kind. ${ }^{21}$ Wenskus R. Stammesbildung und Verfassung: Das Werden der frühmittelalterlichen gentes. Köln; Graz, 1961. 
that determined whether a group's identity was successful or not. It is also generally accepted that the foundation or starting point of a newly created identity is always the commonly adopted new name - the endonymum of the community.

The real question is, however, why some of these new names do not survive the fierce competition (in the market of new identities). The list of examples would be really long. In fact, once a male military community adopts its distinctive name and has on its account a larger number of victories, its glorious history can take off really fast and even last for several centuries. However, it can also fall just as fast rapidly and unexpectedly, as it happened to the «famous» Herules, to mention just one example. On the other hand, though, the names of other male military communities similar to the Herules continued to thrive throughout the centuries to eventually become the modern European nations we know today, certainly assimilating other groups on the way. Of course, this could not have happened if their cultural tradition had not been recorded in writing. Above all, however, this would not have been possible if these «marks» had not been promoted purposefully and individually by the superpower of the Middle Ages: the Church.

In the complexly structured and open set of identifying traits, some old identities are still perceived as modern today and this is precisely for the same reasons for which they originated, namely the fact that their specific names still remind of those, which appear in the written sources around the time the Goths, and the Huns afterwards, invaded the Roman provinces beyond the Danube (as seen from Rome), i.e. Dacia and Pannonia, and the Franks and the Burgundians descended on Gallia west of the Rhine. Among the best known names that have persisted are the Franks — the French, the Angles — the English, the Normans - the Norwegians, and undoubtedly the Slavs as well. Among the Slavs, this mainly applies to those who stuck to their old name, i.e. the Slovaks and the Slovenes.

Another characteristic of this long discussion on the origin and ways those «non-Roman identities» managed to spread all around Europe is that its typical medieval nominalist-realist nature has not changed at all over the centuries. Neither the nominalists, who can be found mainly overseas, nor the realists, based mostly on the continent, can be considered to be completely mutually exclusive. Indeed, this was exactly the case at the peak of the intellectual struggle for the so called realia. However, if you project both these viewpoints on the origin, evolution and transformation of the identities of male military communities in the early Middle Ages onto their equivalent modern nations applying the fringe opinions of the two groups, the nominalists would argue that although some written sources at the fall of antiquity do mention some communities having distinctive names, these are projections of their authors' desires rather than actual entities. Indeed, for modern nominalists, any early medieval gentes are primarily «imagined communities» ${ }^{22}$. It means they have very little or nothing in common with any communities existing at that time or now in spite of having identical or similar names. In other words, the medieval narrative on the new non-Roman political subjects is not any different from present-day fantasy literature, such as the narrative of J. R. R. Tolkien's Lord of the Rings. The conclusion is clear: there are no hobbits just as there were no Longobards or Vandals. This means that there were no Slavs north of the lower Danube at the beginning of the $6^{\text {th }}$ century, just narratives about them. The name of the Slavs is, therefore, not a «proper

22 Anderson B. Imagined Communities: Reflections on the Origin and Spread of Nationalism. revised edition. London; New York, 1991. 
name» (endonymum), i.e. the name by which a military organised male community north of the Danube called themselves, but the name contemporary narrators used for some unidentified barbarians beyond the borders of the Roman Empire without these barbarians knowing about it (exonymum). As the Slavs did not actually exist, they had to be «produced». This is the case of Florin Curta's methodological approach in his work The Making of the Slavs ${ }^{23}$. The argument supporting this claim is the alleged lack of contemporary evidence that those the sources call Slavs really identified themselves as such. ${ }^{24}$ Nevertheless, the weak point of this and other similar hypotheses supported by modern nominalists is precisely the most important question: the motive, i.e. the reason why the «promoters» of the name Slav, i.e. Jordanes, Prokopios, and John of Ephesos would do this in three different languages and most probably independent sources at the same time, i.e. in the mid- $6^{\text {th }}$ century.

Actually, such a methodological approach would have been in serious contradiction with the traditional ancient historiography and geography model, which preferred old and tested names (bona et antiqua nomina) to name and describe any new political units appearing at their borders ${ }^{25}$.

The realists, on the contrary, point to the fact that the apparition of a community with a specific name is one of the the many possibilities the social history of mankind offers. Its origin, apparently the revolutionary identification with the new name (no gradual ethnogenesis, but a revolutionary, ad hoc, and one-off positive decision by a relatively closed community of professional warriors concerning their new name ${ }^{26}$ ), is just the first step in the fulfilment of this possibility.

But even the realists's perception of male military groupings in the early Middle Ages, communities with a well-defined denomination (endonym), also has its shortcomings. The trickiest one of them is the fact that the existence of a community is usually, mostly without any evidence, projected a priori back to times before the name in question actually appeared ${ }^{27}$.

From the methodological point of view, an even worse practise is when a contemporary situation (anticipation) having to do with the spread of a specific identity (name) is moved back into ancient times (ancient history), mostly without any factual support. A perfect example to illustrate this is when the modern inhabitation area of those who consider themselves to be

${ }^{23}$ Curta F. The making of the Slavs. History and archaeology of the Lower Danube Region, c. 500-700. Cambridge, 2001.

${ }^{24}$ The first written record of Slavic self-identification is in the well-known letter, which was supposedly written by Moravian ruler Rastislav to Emperor Michael around 862 and which begins with the words: «We, Slavs, are a simple people» (MMFH.Vol. II. 2nd rev. ed. Praha, 2010. P. 124). It is generally accepted that the text originated between 6 April 885 and the winter of the same year. Similarly, St. Adalbert identifies himself as a Slav before his death with the words: «Sum nativitate Sclavus, nomine Adalbertus, professione monachus, ordine quondam episcopus...» (Kanaparz Jan. Żywot św. Wojciecha / Ed. A. Batowski // Monumenta Poloniae Historica. Vol. I. Lwów, 1861. P. 181).

${ }^{25}$ Dostálová R. Byzantská vzdělanost. Praha, 1990.

${ }^{26}$ Geary P. Ethnic Identity as a Situational Construct in the Early Middle Ages // Mitteilungen der anthropologischen Gesellschaft. 1983. Vol. 113. P. 15-26.

${ }^{27}$ It does not mean, however, that such works do not enjoy considerable popularity among readers. See, for example: Hromník C. A. Sloveni a Slovensko. Martin, 2015; Timura V. Zamlčané dejiny: Pôvod a začiatky Slovenov-Slovákov. Bratislava, 2015, or older publication: Horák A. O Slovanech úlně jinak: Co nebylo o Slovanech dosud známo. Vizovice, 1991. 
Slavs is automatically assigned to different names found in ancient as well as early medieval geography and historiography. These «historicising» practices need to be approached critically and even rejected directly and categorically. In plain words, nobody who lived before the endonym Slav appeared in the written sources can be tagged as Slav.

The collective consciousness of every community is fundamentally connected to the cultural tradition of the memory they share (memoria). The origin of the common memory is the codified account of the events that gave birth to the community or made it stronger. Here, to «codify» means to adopt the official version of the story (fabula) by all its relevant characters and/or its main protagonist or hero (leader, prince). This memory is always created retrospectively and as a commission. This story can be delivered in many ways. The most archaic one is known as folk tradition, which includes performances by itinerant igrici (ioculatores, skaldi) as well as spontaneous works by anonymous authors. These often intertwined, too. Sometimes the commissioned «community memory» reached a highly elaborated written form as it is the case of Virgil's Aeneid commissioned by the Romans. However, both The Aeneid as well as folk tradition create narratives that justify the unparalleled origin of their commissioner as well as the point and moment the community came to be (origo). By doing so, they also retrospectively justify and legitimise the contemporary situation of the community as well as its legal and political ambitions.

The cultural memory of any male military community, then, consists of its constant specific name (endonym) and the narrative that legitimises its right to exist. The narrative can also be considered an identification trait of their common memory. The identification traits of the community can also be variable. Together they represent the contemporaneous, that is, the very current meaning and power (vis) of the community's name. The absence of the community's specific name in the sources is, like it or not, enough reason to stop considering any possible previous existence of this community. Should any of us consider the possibility that the Slavs existed under a different name before their specific endonym demonstrably appears in written sources - as they used to and still do in order to produce «Slavic antiquities» — this would result in a host of arbitrary and never-ending speculations that go against any kind of logic and, therefore, cannot be subjected to even the most elementary scholarly criticism. Unfortunately, the truth is that precisely this kind of opinions still enjoy great popularity among a considerable group of people. If you apply this kind of approach to the Slavs, for example, it would also mean that the Slavic history could be automatically associated with the ancient history of the Illyrians or the Sarmatians ${ }^{28}$. It is understandable that similar opinions were frequent in baroque historiography, but today they are already outdated and there is no further need to mention them any longer.

It has already been said that one of the main features — and also the biggest weakness of this global and certainly costly discussion on the way the different non-Roman identities spread and became established after the Roman Empire partially collapsed is the fact that - with just a few exceptions - there are no serious analyses of the circumstances that made it possible for the identity of the most numerous community in Europe, i.e. the Slavs, to achieve permanent acceptance and recognition. Most serious analyses of how the "brand" Slav originated and became established do not go beyond presenting the views of

${ }^{28}$ See: Homza M., Rácová N. K vývinu slovenskej myšlienky do polovice 18. storočia. Bratislava, 2010. P. 136ff. 
archeologists. These premise on the material culture being in connection with some kind of social self-identification. No matter how sophisticatedly substantiated they may appear ${ }^{29}$, I consider such argumentation to be a priori incorrect. Another thing is the growing presence in the media of the current interpretations of the so-called Slavic ethnogenesis, which the archeologists present to the public with unprecedented persistence. In my opinion, this results from the fact that these interpretations combine a specific archeological paradigm with apparently convincing natural-scientific, i.e. «factual» arguments, rather than from the ability of archeologist and archeology alone to give an explanation for the very issue in question. In fact, I see little difference between the idea of Slavdom in the first pictures of the cycle The Slav Epic by painter Alfons Mucha and the idea that the Prague and other type of ceramics or buckles constitute veracious evidence of a distinctive «Slavic culture» and, consequently, of some Slavic identity as well. However, I can understand that the strength of this «scientific» perception of the origins of the Slavs results from the «gruelling» search for some material expression of the Slavic nature rather than from the persuasive power of the evidence presented to support that what the archeologists tag as Slavic was, in fact, Slavic.

The «creation» of this «science» emerged in the confrontation with the extensively presented and «scientifically objectivized» Germanic past, at least from the beginning of the German Empire (1870), and later mainly during the Third Reich (1933-1945). «Slavic archeology» owes much of its acceptance and recognition to the undoubtedly impressive victory of the «Slavs» in the Great Patriotic War (WWII) in 1945. The victory of «Slavic» weapons, however, could not have meant the defeat of critical thinking, nor of Man's ability to use criticism to corroborate the veracity of his or her conclusions. This especially applies to the conclusions (or rather inner-convictions) of archeologists on what the Slavs actually are and what they are not. Their verification methodology for the materialised «Slavdom» can be described as follows: in order to confirm their convictions about the Slavs in a specific space and time, they first suppose and then present relevant proof (typical Slavic material culture $)^{30}$. The verifiable value of the «proof», however, does not reside in the information power of the source — as it cannot declare anything by itself — but in the archeologists' pre-defined judgments used to classify and categorise their discoveries. The findings of their research are then published and cross-cited in scholarly literature. The truth is that any conclusions of archeological research claiming that «the Slavs arrived at this place in this or that year» fall short of the most important thing: the possibility to verify the archeologists's conviction that the bearers of the attributed «Slavic» material culture did, in fact, identify themselves as Slavs. Indeed, a description of a material culture remains just a description of that culture. Without a demonstrable correlation between archeological and other, mainly, written sources, any archeological reconstruction of the «old Slavic» world is nothing but a

${ }^{29}$ The most influential position in this undestanding has the school that formed around Michat Parczewski in Krakow. See: Archeologia o początkach Słowian. Materiały z konferencji, Kraków, 19-21 listopada 2001 / Ed. by P. Kaczanowski and M. Parczewski. Kraków, 2005.

${ }^{30}$ On the criticism of the method, see: Jones $S$. The Archaeology of Ethnicity: Constructing identities in the past and present. London, 1997. P. 115; but especially, Curta F. From Kossina to Bromley - Ethnogenesis in Slavic Archeology // Barbarian Identity: Critical Approaches to Ethnicity in the Early Middle Ages: Studies in the Early Middle Ages / Ed. by A. Gillett. Turnhout, 2002. P. 201-218. 
hardly verifiable hypothesis. Therefore, the methods archeologists use cannot be considered to be the «hermeneutic circle» but only «a section of the circle».

Likewise, the linguists's theories on the origin and inexplicable successful spread of the Slavic identity in Europe and Eurasia have failed to deliver any satisfactory conclusions. However, it is necessary to admit that linguistics, especially paleolinguistics, has the potential to shed new light on the topic, especially in combination with other sociolinguistic research. For example, some lexical borrowings or basic words contemporary Slavic languages have in common, can also be found in the Old Gothic language, for instance: prince, bread, sword, regiment, helmet, armour, cattle, shed, room, and others (in Slovak: knieža, chlieb, meč, pluk, helma, brnenie, skot, chliev, izba, etc. $)^{31}$. On the other hand, except for eastern Slavic languages, the amount of archaic words of Turkic origin among the basic vocabulary of Slavic languages and dialects is insignificant. The only exceptions in this respect are Bulgarian and Macedonian, but here again, this the result of centuries of Ottoman rule rather than of earlier historical circumstances at the time of the Avars, of Bulgarian khan Asparuch, or of the Hungarian tribal union.

Nevertheless, the role of linguistics and archeology in solving and understanding some aspects of the complex question of the massive expansion of the trademark «Slav» in the $6^{\text {th }}-9^{\text {th }}$ centuries cannot be denied.

In my opinion, the key to a more satisfactory understanding of this issue is to comprehend the inner dynamics and evolution of the content of the term Slav. As already said, this name, Slav, had a different vis in the $6^{\text {th }}$ century, another in the $9^{\text {th }}$ century, and a different one today. Likewise, in a closer or more distant future it will not necessarily mean the same as it does today. This explains why it is so difficult to understand the synchronic and diachronic aspects of the matter in hand.

In the late $20^{\text {th }}$ and early 21 st century, several scholars have attempted to take into consideration the multilayer character of the question of the origin and expansion of the Slavic identity. Let me mention Walter Pohl ${ }^{32}$ and Przemysław Urbańczyk ${ }^{33}$ to complete the list of the already mentioned ones, i.e. Florin Curta, Paul Barford ${ }^{34}$, Daniel Dzino ${ }^{35}$, and Sebastian Brather $^{36}$. These authors also apply a dynamic rather than a static approach when trying to understand the «birth» (origo) and other aspects of the Slavic identity. However, due to the inconsequence and speculativeness of their arguments, as well as to the persistent naivety that does not allow them to get rid of that Herder-like ideal of the Slavs — which can still be felt in some analyses, - their reasoning mostly fail to gain general acceptance. In fact, any attempts to shed light on the «obscure Slavic ethnogenesis» by substituting it with the equally semantically void term «Slavic acculturation» — as Walter Pohl does — can hardly be

${ }_{31}$ Pritsak $O$. The Slavs and the Avars // Settimane di studio del centro italiano di studi sull'alto medioevo. Vol. XXX: Gli Slavi occidentali e meridionali nell'alto medioevo. Spoleto, 1983. P. 421. ${ }^{32}$ Pohl W. 1) Die Awaren. P. 94-127; 2) Początki Słowian. P. 11-27.

${ }^{33}$ Urbańczyk P. Władza i polityka we wczesnym średniowieczu. Wrocław, 2000. P. 89.

${ }^{34}$ Besides cited works, see: Barford P. The Early Slavs: Culture and Society in Early Medieval Eastern Europe. London, 2001.

${ }^{35}$ Dzino $D$. Becoming Slav, becoming Croat: identity transformations in post-Roman and early medieval Dalmatia. Leiden, 2010.

${ }^{36}$ Brather S. The Archaeology of the Northwestern Slavs (Seventh to Ninth Centuries) // East Central Europe. 2004. Vol. 31. No. 1. P. 78-81. 
considered to be a historical and critical evaluation of extant sources or as a new interpretation of actually available facts on the apparition of the Slavic identity ${ }^{37}$.

This paper aims at getting rid of most of these more or less romanticising views and, instead, try to explain the «puzzling» spread of the Slavs by trying to understand the contemporary meaning of the extant written sources. My intention is to grasp the spreading of the Slavic identity - especially in its first phase — by understanding the mechanics of the successful promotion of a new «trade mark» or name on the market.

Just like any other company, «the company Slav» has an exact starting point, which determined its base. The foundations of Slavic identity were laid after the structures of the Roman Empire started to brake up in the second half of the $5^{\text {th }}$ and early $6^{\text {th }}$ centuries. Indeed, this can be put in direct connection with the fact that the writers and historians of that time, namely Jordanes, who wrote in Latin ${ }^{38}$, Prokopios in Greek ${ }^{39}$ and John of Ephesos in Syrian $^{40}$, - against all customary rules of contemporary scholarship — used the name Slavs to refer to a new political subject that had appeared in the Barbarian political scene beyond the Danube.

Obviously, all three authors just described the real political situation that existed at the other side of the Danube during their lifetime. Therefore, it cannot be a mere invention, as Florin Curta would have it, i.e. a constructed umbrella term ${ }^{41}$ for various groupings of barbarians who just happened to live north of the new Roman border - but a report on a new noteworthy political subject known by this and not other name, which had appeared across the lower Danube and represented a threat for the Eastern Roman Empire.

However, the beginning - origo ${ }^{42}$ — or sudden «apparition» of the Slavs, is not as surprising as those who have been writing and speaking about it recently claim, but just like in many other cases (the Burgundians, Bavarians, Saxons, Frisians, Old Goths, Franks, as well as the already mentioned Herules and Vandals), the Slavs originated as the result of broad economic, legal and social movements within the Barbaricum, i.e. beyond the contemporary borders of the Roman Empire. In his major work Getica, Jordanes uses Scandinavia and the delta of the Vistula river as pars pro toto for the entire Barbaricum. In his opinion, this space is a vagina nationum, a term that needs no translation, as well as an officina gentium, i.e. the «workshop in which nations / tribes are made» ${ }^{43}$. However, it is precisely Jordanes' work

${ }^{37}$ Sometimes in a slightly comical form in Walter Pohl's rendering. His tenacious search for the attractiveness of the diffusion of Slavic identity is dictated either by the overt admiration for Herderian stereotype of Slavs as «incorrupt children of nature» fixed in historiography for centuries, or subconscious projection of anarchic features of the hippies, flower-power movement in the 1960s and 1970s.

${ }^{38}$ Iordanis. Getica, V et XXIII. (MGH. Auctores antiquissimi. Vol. 5. P. 62-63; 88-89).

${ }^{39}$ Procopius. De bello gothico II, 15 (Corpus Scriptoriae Historiae Byzantinae. Pars 2. Vol. 2 / Ed. B. G. Niebuhr. Bonnae, 1833. P. 205).

${ }^{40}$ История Иоанна Эфесского (I, 23) // Пигулевская Н. В. Сирийские источники по истории народов СССР. М., Ленинград, 1941. С. 114.

${ }^{41}$ Curta F. The Making of the Slavs: Slavic Ethnogenesis Revisited // MESS and RAMSES II. Mediterranean Ethnological Summer School. Vol. 7 / Ed. by J. Repič, A. Bartulović, and K. Sajovec Altshul. Ljubljana, 2008. P. 281.

${ }^{42}$ Plassmann A. Origo gentis: Identitäts und Legitimitätsstiftung in früh- und hochmittelalterlichen Herkunfterzählungen. Berlin 2006.

${ }^{43}$ Iordanis. Getica, IV (MGH. Auctores antiquissimi. Vol. 5. P. 60). 
that reveals that, for whatever reason, the late Roman authors did not fail to reflect deeper on these new identities.

Consequently, the question is not where the ancient homeland of the Slavs was located, what the ideal «old Slavic» language looked like, nor how the «Old» Slavs formed beyond the Carpathians and how they arrived at the lower Danube - where Jordanes, Prokopios and John of Ephesos locate them, and after them many others, including the earliest written Slavic tradition (Nestor the Chronicler and the Account on the translation of books into the Slavic language $\left.{ }^{44}\right)$. By the use of reason it is not biologically possible for some «self-conscious» Slavs to reproduce in their «ancient homeland» to such numbers to make it possible for them to populate over half of Europe in just 300 years. Likewise, there is no material evidence to prove - and it is practically impossible to prove — that being farmers, they would wander tens, hundreds and even thousands of kilometres from hypothetical point A to point B with their families, stock, and food supplies. This idea needs to be be forgotten. It resembles the Old Testament narrative about the origin of the chosen Jewish nation in Egypt, their fortyyears-long wandering and settling down in the «Promised Land», rather than proper scientific reflection. In fact, the relevant question is: What did the «trademark» Slav owed its success to? This question needs to be answered using the latest historiographical trends, i.e. finding out what the vis of the name Slav meant in this or that period and how, i.e. by what means this identity managed to spread within a particular historical period.

It was in the mid-1990s that I first started to focus on the origins of the Slavic identity and its success on the «market» of European and world identities ${ }^{45}$. Over all those years, as this paper illustrates, the premises and terminology that would help us find a satisfactory explanation to this issue needed to be reconsidered again and again. In the meantime, some of my students have elaborated on some specific aspects of this question - especially Nora Malinovská (born Verešová) ${ }^{46}$ and Adam Mesiarkin ${ }^{47}$. For the purposes of this paper, I have summarised the knowledge I have so far managed to gather into several major theses on the

${ }^{44}$ Шахматов А. А. Сказание о преложении книг на словенский язык // Jagić-Festschrift: Zbornik u slavu Vatroslava Jagića. Berlin, 1908. P. 181. - See also: Флоря Б. Н. Сказание о преложении книг на словенский язык: Источники, время и место написания // Byzantinoslavica. 1985. Vol. 46. №. 1. Р. 121-130; Свердлов М. Б. К истории великоморавской культурной традиции на Руси конца XI - начала XII в. // ПИЖ. 2015. Вып. 7. № 3. С. 10-21. - Unlike the cited authors, I place the creation of the archetype of the Tale on the translation of the books to the court of Prince Kocel' in Pannonia and date it to the end of 860s and first half of the 870s.

${ }^{45}$ Homza M. 1) Niekol'ko téz k počiatkom slovenského etnika // SAS. 2002. Vol. 31. P. 285-295;

2) Stredná Európa..., passim; Homza M., Rácová N. K vývinu slovenskej myšlienky. P. 7-121.

${ }^{46}$ Verešová N. 1) Vývoj chápania geografického termínu Sklavínia v historických prameňoch 6.-14. storočia // Historický zborník Matice slovenskej. 2008. Vol. 19. No. 1. P. 124-143; 2) Povest' vremennych let a jej koncepcia Slovienskoj zemli // Historia Nova. Vol. II: Śtúdie k jubileu Pavla Jozefa Šafárika. Bratislava, 2011. P. 12-20; Malinovská N. [Малиновска Н.]. 1) Gеоgraphical Concepts of Sclavinia in Historical Sources from the Sixth to the Fourteenth Century, with an Emphasis on the Moravian-Pannonian and South Slavic Tradition // Slovakia and Croatia. Historical Parallels and Connections (until 1780) / Ed. by M. Homza, J. Lukačka, and N. Budak. Bratislava; Zagreb, 2013. P. 60-65; 2) «Regnum Sclavorum» Святополка как источник средневековых славянских концепций «Склавинии» // SSBP. 2017. No. 1. C. 21-38.

${ }^{47}$ Mesiarkin A. 1) The Basis of Research into Croatian and Slovak Ethnogenesis // Slovakia and Croatia. Historical parallels and connections (until 1780) / Ed. by M. Homza, J. Lukačka, N. Budak, 
reasons for the «puzzling» success of Slavic identity. These, of course, cannot be considered to be final by any means.

1) The Slavs constituted themselves by adopting their distinctive name, the Greek word $\Sigma \kappa \lambda \alpha \beta \eta v o i$, which in its latinized form is Sclavi, and in the original language Sloväni (Slovl'eni). The name appears in writing for the first time, with some retrospective validity, around the year 551 and — most interestingly — at the same time at three different places, within three different cultures and systems of writing - Greek, Latin, and Syriac ${ }^{48}$. It is a «descriptive» name, as its etymology shows - from the word «sláva» («slávni»), i.e. «glory» or «slovit»», i.e. «word», «to speak» ${ }^{49}$. Both interpretations are logical. While the former emphasises the character of the society, which adopts the name for the chosen and best warriors, the latter accentuates the opposition «us» against «them», i.e. we, who know the word and, therefore, can speak, and they, who do not and therefore cannot (in Slovak «nemí» means «mute» and its derivate «Nemci» means Germans). Both terms mirror the actual political situation in the former Roman provinces on the middle and lower Danube after the institutions representing the late Roman public administration had left. They premise on one thing — the formation of a male military group which adopts its distinctive name based on their glorious deeds and/ or on the common language of communication.

The apparition of the Slavs as a special political unit (gens, Männerbund) is, therefore, connected with different legal, political, religious, cultural as well as economic processes going on at the turn of the $5^{\text {th }}$ and $6^{\text {th }}$ centuries in the vast areas around and far beyond the old Roman limes. Precisely these processes brought into the light of written history some political subjects, many of them new ones, that had hitherto remained practically unknown to the contemporary educated world. These subjects were alike and had similar inner structures, but differentiated themselves outwards by their distinctive names.

The imaginary point from which it is possible to speak about the actual existence of the Slavs is their first — recorded - crossing of the Danube. Precisely this event and the subsequent presence of the Slavs in the Gothic war during the reign of Emperor Justinian (527-565) were the reason why the three most important reporters of that time, namely Jordanes, Prokopios and John of Ephesos, noticed them ${ }^{50}$. By that time, however, the Slavs already existed as a defined and influential military group. Most probably nobody will ever know with certainty what was the primordium, «primordiale Tat» or «primary deed ${ }^{51}$ that resulted in part of the population north of the lower Danube - which had become unified by wars and battles - making a political decision that would eventually prove to have farreaching consequences, i.e. to start identifying themselves with a new, until then unknown name. Hypothetically, however, it is possible to suppose that the triggering moment occurred before a battle most likely to have taken place somewhere at the banks of the Ipel' (Ipoly)

V. Kucharská, S. Kuzmová, A. Mesiarkin. Bratislava; Zagreb, 2013. P. 38-42; 2) Veča príspevok k dejinám slovanského práva // HČ. 2016. Vol. 64. No. 2. p. 333-360.

${ }^{48}$ Pritsak O. The Slavs and the Avars. P. 365-366.

${ }^{49}$ See entry «Slovák, Slovan» in: Králik L. Stručný etymologický slovník slovenčiny. Bratislava, 2015. P. 539-540.

${ }^{50}$ Montinaro F. Byzantium and the Slavs in the Reign of Justinian: Comparing the Two Recensions of Procopius's Buildings // The Pontic-Danubian Realm in the Period of the Great Migration / Ed. by V. Ivanišević and M. Kazanski. Paris; Belgrade, 2011. P. 89-114.

${ }^{51}$ Plassman A. Origo gentis... 
river in 469 , which would become known as the Battle of Bolia and is mentioned by Jordanes in his Getica ${ }^{52}$.

For it was after this battle that the political forces, which for the next 100 years were to decide about the destiny of the middle and lower Danube after the Ostrogoths left for Italy — namely the Slavs and the Gepids - took shape ${ }^{53}$.

It was Prokopios who referred in a more detailed manner ${ }^{54}$ about the Slavs entering the stage of history during the reign of Emperor Justinian. However, they certainly do not appear to be a peaceful «people of doves» — as the supporters of the Herder-like idea of Slavdom would like to have it — but as an already successful military group and an influential political subject. The fact that Constantinople tried to secure their services in the Gothic war means that they must have been familiar with their previous military success. The primary and decisive reason why they knew of the fame, «the glory» of the Slavs must have been the previous successful operations of this subject. The number of new «Slavs» joining the original and certainly not so numerous group is very likely to have depended on the scale of their success. As the scholars have repeatedly stated, the only important issue for this kind of male communities was to have a common political and military goal. At this crucial time, the bearers of the identity themselves, i.e. the soldiers (milites), were the only factor that decided whether their new identity spread or not. The only exception was the Eastern Roman Empire, within which the Romans still lived and operated ${ }^{55}$. The fastest and most effective way to promote one's name and, thus, one's identity was, indeed, to be successful in warfare.

It is not by chance that the privileged military class among the Slavs was called «the victors» («vít'azi»). This word - certainly not accidentally — has a lot in common with the Germanic expression wiking, which denotes a warrior who, after a victorious battle, is entitled to a share of the booty ${ }^{56}$. The Slavic victors («vít'azi») gathered in arrays («voje») ${ }^{57}$, in a militarily organised community of comrades («sú-druh»), i.e. a retinue («družina») and spread their fame - the heroic name under the leadership of experienced military commanders -

\footnotetext{
${ }^{52}$ Iordanis. Getica, LIV (MGH. Auctores antiquissimi. Vol. 5. P. 130).

${ }^{53}$ In some respect close to my opinion is the view of Omeljan Pritsak, who understands the Slavs as «military colonists» who formed as «post-Gothic» institution in the period after the death of Attila in 453. See: Pritsak O. The Slavs and the Avars. P. 399: «The Sclaveni appear in Jordanes`s catalogue of the kinds of professional warriors known to him (at the end of $\S 119$ ) as an obvious addition made to glorify his hero Hermanarich. From this we can deduce that the Sclaveni were a post-Gothic institution, that is, after 400, since no Sclaveni of Attila were known either to the eyewitness, the Byzantine diplomat Priscus who visited Attila in 448, or to the Gothic traditions used by Jordanes. Thus the Sclaveni must have developed after Attila's death in 453». Unfortunately, I cannot agree with other theses of the author, according to whom the Slavs were above all an invention of nomadic communities, who used the militarily trained Slavs, like later mameluks in Egypt or Syria as «infantry» during their expansion.

${ }^{54}$ Prokopios. The Wars of Justinian / Transl. by H. B. Dewing. Revised and modernized, with an Introduction and Notes by A. Kaldellis.

${ }^{55}$ Geary P. J. Barbarians and ethnicity // Interpreting late antiquity: Essays on the postclassical world / Ed. by G. W. Bowersock, P. Brown, and O. Grabar. Cambridge; London, 2001. P. 108. ${ }^{56}$ See entry «Vít’az» (Victor, Winner) in: Králik L'. Stručný etymologický slovník slovenčiny. P. 662.

${ }^{57}$ Ibid. p. 665-666.
} 
voivodes, subordinated to the centre (the leader, the dynasty - the princes $)^{58}$. It was this in many ways attractive layer of leaders that in the earliest stage of the military male community were not only its political and military representatives but also its symbol and, above all, the commissioners of the community's «memory» ${ }^{59}$.

Making use of literary abbreviation (synecdoche) typical for that type of retrospectively created literary tradition, which concentrates and conserves a group's collective memory, this period can be described in the words of Nestor the Chronicler as follows: «There was one Slavic people, which lived on the Danube». This can be interpreted as: a male military community, which called themselves Slavs, formed on the Danube. On the northern banks of the lower Danube appeared a new political subject, gens, an influential male Männerbund, whose successful military policy (mainly between 540 and 550, and later between 570 and 590) resulted in its new name spreading like fire.

2) Every expansion will eventually reach its spatial, time and material limit, beyond which it either ends, becomes stable or — at times — turns against itself. After the initial period of successful warfare, during which the new Slavic identity attracted all those who took part in the campaigns, a new stage inevitably followed whose main question was the inner differentiation of the «mass» of Slavs. On the other hand, however, it also needs to be said that the sense of identity of a male community resulting from a single battle or war is usually unstable. It arises and falls ad hoc, is guided by a common military goal and the subsequent participation in the relevant military campaign. Logically, once the campaign is over, the number of the bearers of the new name falls significantly. The Miracles of St Demetrios ${ }^{60}$, which relate to the Avar-Slavic description of the siege of Thessaloniki in 618, already give account of the inner division of the Slavs. Besides the Slavs, it mentions other military groups as well. These groups in part counted as Slavs and in part did not ${ }^{61}$. The number of Slavs was, therefore, as unstable at the beginning of their history as it is today. The issue here is basically the natural phenomenon of double or multiple identity also found in other «male communities» that developed in the Barbaricum according to the same rules as the Slavs. The unstable character of the number of bearers of the name Slav immediately showed in two ways. The number of Slavs increased and decreased especially outwards, i.e. all those who were willing to be identified with the name under certain circumstances. However, the number of Slavs was not stable inwards either - all those who identified themselves with the name under all circumstances. Certainly, once a successful military campaign was over, their number regularly reduced to the «true» or «authorised» bearers of this name, memory

${ }^{58}$ P. Urbańczyk's mechanical assumption of a sort of pre-tribal, family community of ethnically self-conscious Slavs of egalitarian character is in no way right. See: Urbańczyk P. Władza i polityka... P. 89.

${ }^{59}$ Pohl $W$. Staat und Herschaft im frühen Mittelalter: Überlegung zum Forschungstand // Staat im frühen Mittelalter: Forchungen zur Geschichte des Mittelalters / Ed. by A. Stuart, W. Pohl, and H. Reimitz. Wien, 2006. P. 25. To the functions of the retinue («Männerbund») in Slavic societies pointed in an older article see also: Graus $F$. Raně středověké družiny a jejich význam při vzniku států ve střední Evropě // ČČH. 1965. Vol. 13. No. 1. P. 15.

${ }^{60}$ Miracula Sancti Demetrii: Les plus anciens recueils des miracles de Saint Démétrius et la pénétration des Slaves dans les Balkans. Le texte. Vol. I / Ed. P. Lemerle. Paris, 1979. P. 81-93. ${ }^{61}$ See description of the battle of Thessaloniki in: Hurbanič M. Posledná vojna antiky: Avarský útok na Konštantínopol roku 626 v historických súvislostiach. Bratislava, 2009. 
and tradition (in German language Traditionskern, or rather «Trägern einer Tradition» ${ }^{62}$ ). They were joined by others who could be enchanted and influenced by the powerful appeal (aesthetics, magic) of the Slavic tradition. The «bearers of tradition» were the very institutions of a transcendent, far-reaching, or - in Jan Assman's words - «cultural memory $\rangle^{63}$. Under collective cultural memory we understand a set of basic identification features of a community. Some selected individuals or heroes (Achilles, Agamemnon, Paris, Hercules) are at the same time the representatives and the transmission channels of the community's shared cultural tradition. In archaic times, or in the pre-written period - just like the Greeks before Homer or Rome before Vergil - a selected group of the military and/or priestly elite became the bearers of the cultural tradition. The unwritten condition for the exclusive right to use and spread the «distant memory» of the community was mostly the inherited share of the old glory, i.e. the blood ties between two, three, and more generations of descendants and those who directly contributed to the glory and prestige of the new mark or identity. Besides the glory of lineage, however, just like Ulysses - or among the Slavs perhaps King Samo - also the idoneitas or «suitability» of an individual determined whether or not they could also be participants of the «distant» memory of the community.

For the preservation of the «distant memory» is also important the physical closeness of the memory bearers to the dynasty and its court or courts. The dynasty formally rules and leads the community, and symbolises it outwards. The concentrated past of the society, i.e. the essential memory layer of the community, was transmitted orally in the presence of the ruler at different ritual sessions - banquets, weddings, burials, etc. — by an early form of singers (ioculatores/igrici). As Sebastian Brather, among others, noticed, the intensity and quality of self-identification with some kind of linking, i.e. mutually communicable and understandable memory, rises and falls depending on the epicentre it radiates from ${ }^{64}$. This epicentre is usually the ruler. At the same time, the ruler and their lineage or dynasty guarantee the long-lasting and enduring character of the community. Just like with other post-Roman identities, the core of this rather primitive form of «institutionalisation» of the community's memory is the description of the glorious military deeds or acts of their different heroes. Reinhard Wenskus claimed that the proven class of bearers of tradition was able to transmit the «representative memory» of the community over quite long periods of time or saecula saeculorum, i.e. forever and ever. In other words, the «representative distant memory» of a community lasts as long as its last representative - for example The Last of the Mohicans by James Fenimore Cooper.

The written (literarily recorded) echo of this basic Slavic tradition, i.e. the most archaic layer of the Slav's mnemosyne or memory, can apparently be found in the oldest layers of three Slavic chronicles: the Chronicle of the Priest of Dioclea ${ }^{65}$, the Russian Primary Chronicle (especially the Account on the translation of the books ${ }^{66}$ ), and the Chronicle of Archdeacon Thomas of Split ${ }^{67}$ as well as in the Greek narrative in the work «On the Administration of the

${ }_{62}$ Wenskus R. Stammesbildung und Verfassung: Das Werden der frühmittelalterlichen gentes. Köln; Graz, 1961.

${ }^{63}$ Assman J. Collective Memory and Cultural Identity. P. 125-133.

${ }^{64}$ Brather S. Ethnische Interpretationen... P. 104-117.

${ }^{65}$ Presbyteri Diocleatis Regnum Sclavorum // MMFH. Vol. 1. P. 241-245.

${ }^{66}$ Шахматов А. А. Сказание о преложении книг...

${ }^{67}$ Toma Arhiđakon. Historia Salonitana: povijest salonitanskih i splitskih prvosvećenika / Ed. by O. Perić. Split, 2003. 
Empire» by Emperor Constantine VII Porphyrogenitus ${ }^{68}$. The first and the third chronicle written in the milieu of the West Balkans refer to a common Slavic-Gothic (or Gepid) origin of the Slavs ${ }^{69}$. The unknown author of the account «On the translation of the books» describes the invasion of the Vlachs and other nomads to the «Slavic land». This anonymous author also reports quite extensively on the period of Slavic-Avar cohabitation. Emperor Constantine Porphyrogenitus also speaks of the Gothic past of the Croatians (Slavs?). He not only confuses, but even identifies the Slavs with the Avars. On the other hand, the Priest of Dioclea presents an entire genealogy of the Svevladids, from which — in his opinion - came the Goth leaders Ostroil and Totilo, conqueror of Rome, but also (Moymirid) Svatopluk and other Slavic dynasties from the western Balkans.

The last source demands a closer look, indeed. The archaic character of the system of personal proper names the Priest of Dioclea presents in it, which in this case consists of bithematic princely names whose most frequent elements are the suffixes - mir and $-s l a v^{70}$, in my opinion constitutes the most important argument supporting, among others, the existence of a single original Slavic dynasty. According to the Priest of Dioclea, this dynasty could have been a branch of the Amalians. The Amalian names preserved in Jordanes' Getika would corroborate this (Valamir, cca. $\uparrow 470$; Vidimir, $\uparrow 473$, and Tiudimir, $\uparrow 475$ ). The stability of these themes in the construction of the memory of the central dynasty of the Slavs — from which the Croatian Trpimirids as well as the Moravian Moymirids may have originated - fulfils the same mnemotechnical function as the alliteration principle in the system of names of the oldest «mythical» rulers in different Germanic literary narratives. Based on this information about the Slavs it would, therefore, be possible to confirm Reinhard Wenskus' already mentioned thesis on the long-lasting transmission capabilities of the «tradition bearers».

It was a specific part of the society, which identified with its new name and contemporary content, that made it possible for the unusual status of the new, but in the course of the $6^{\text {th }}$ century proven, «Slavic mark» to perdure in the history of Europe. Thus, it can be said that the existence of this community in this period was subject to the same rules as it was the case of other similar male communities known in contemporary Europe. The next stage in the gradual expansion of this mark in the new historical and political conditions must be seen in connection with the natural spread of the distinctive name Slav. This applies most of all to those environments the armed men from the prince's circles who admired this name and its tradition managed to control both formally - through the effective use of power, as John of Ephesos reports in the second half of the 6th century: «they [the Slavs] learnt to fight better than the Romans» — as well as mentally — through the gradual indoctrination of their «stories». Nestor the Chronicler calls it the period when the Slavs left the Danube ${ }^{71}$.

Therefore, the «break-up» of the Slavs before as well as after the arrival of the Avars needs to be understood as the dissemination of the identity of an elite diaspora ${ }^{72}$ into an environment

${ }^{68}$ Constantine Porphyrogenitus. De administrando imperio / Greek text ed. by Gy. Moravcsik; Engl. transl. by R. J. H. Jenkins. Washington, 1967.

${ }^{69} \mathrm{I}$ am inclined in my texts to accept the interpretation that Slavs, similarly to Gepids, are the effect of the division of Ostrogoths. See: Homza M. Stredná Európa... P. 32-33.

${ }^{70}$ Литвина А. Ф., Успенский Ф. Б. Выбор имени у русских князей X-XVI вв. Династическая история сквозь призму антропонимики. М., 2006.

${ }^{71}$ ПВЛ. С. 8.

${ }^{72}$ Abrams L. Diaspora and Identity in the Viking Age // EME. 2012. Vol. 20. P. 17-38. 
that had not yet achieved the military, economic and cultural level of the post-Roman era ${ }^{73}$. In time terms, the upper horizon of the earliest history of the «Slavic trademark» can be delimited between the unknown moment of their revolutionary formation (situational naming) and the conquest of Sirmium by the Avars around the year 568 .

3) From the end of the $6^{\text {th }}$ century the Slavs as a particular subject got in mutual interaction with the steppe Avars ${ }^{74}$. It is a rather interesting period, in which the oldest layer of the Slavic identity had to face the technology of a centuries-long developed and, thus, highly sophisticated nomadic cultural tradition ${ }^{75}$. As history has shown, «the bearers of the name and memory» of the Slavs not only managed to deal with the new situation quite comfortably, but - unlike those known by the names of Gepids and Longobards and, in the end, unlike the Avars themselves, - were also able to take their «Slavic trademark» over to the following centuries as well. The question of how this exactly happened has not been answered satisfactorily until today. The Danubian Slavs, namely, just like their allies the Gepids, were militarily defeated by the Avars. Despite that, however, they did not become their subordinates, unlike their former allies - as Paul the Deacon reports ${ }^{76}$ - and their neighbours the Anti/Ants, to whom the Slavs were genetically tied to according to Jordanes. Obviously this was no standard situation as the rule is that the defeated subject is most likely to eventually disappear. There are several possible explanations for this phenomenon ${ }^{77}$. At this point let me direct my attention to another issue, though. Namely, to the fact that the Slavs were able to overcome the temporary threat to their identity although nobody had recorded their historical narrative in writing. In fact, nobody wrote down the memorial narrative of the main deeds of their rulers, as Jordanes and Prokopios did for the (Ostro)Goths, Isidore of Seville for the (Visi)Goths, the Vandals and the Suevians, Gregory of Tours for the Franks, or Paul the Deacon for the Longobards. Nevertheless, the sources from the end of the $8^{\text {th }}$ and the beginning of the $9^{\text {th }}$ century show that, in the end, the Slavs came out of their interaction with the Avars strengthened to such extent that precisely they became the heirs of the political legacy of the Avar Khaganate in the Danube Basin and the surrounding territories. In many ways, this situation reminds of the beginnings of Kievan Rus' under the rule of Prince Vladimir Svyatoslavich ( $† 1015)$, which was marked by the collapse of the nomadic Khazar Khaganate caused by his father Svyatoslav Igorevich.

Although there is only partial information on the archaic layer of the Slavic memory, the success and further successful spreading of the rediscovered Slavic identity in the times of the «Avar peace» would have hardly been possible if the «formative» aspect of the Slavic memory had not been taken into account ${ }^{78}$. In both cases, the victorious tradition of the Slavs,

${ }^{73}$ See more on this in: Homza, M. Stredná Európa... P. 47-49.

${ }^{74}$ Pritsak O. The Slavs and the Avars. P. 353-435. - See also: Avenarius A. K problematike avarsko-slovanského vzt’ahu na dolnom Dunaji v 6.-7. stor. // Slovanské štúdie. 1971. Vol. 11. P. 223-244.

${ }^{75}$ Крадин H. Н. Кочевники Евразии. Алматы, 2007. C. 355ff. See also: Tyszkiewicz L. Koczownicy turecko-mongolscy a migracje Słowian // Wedrówka i etnogeneza w staroźytności i w średniowieczu / Ed. by M. Salamon and J. Strzelczyk. Kraków, 2004. P. 193.

${ }^{76}$ Pauli Diaconi. Historia Langobardorum, II, 27 (MGH: Scriptores in usum scholarum / Ed. G. Waitz. Hannoverae, 1878. P. 81).

${ }_{77}$ Avenarius A. Die Awaren in Europa. Amsterdam, 1974; Pohl W. Die Awaren... P. 94-127.

${ }^{78}$ Assman J. Collective Memory and Cultural Identity. P. 132. 
which was strengthened further by their alliance with the Avars, gave energy to the «formative power» of the Slavic identity.

In connection with the period of the Slavic-Avar cohabitation on the Danube and with the at first sight surprising «radiance» of the Slavic identity after 796, which brought about the fall of the Avar Khaganate, it is also possible to speak about another, namely the "normative» ${ }^{79}$ aspect of the oldest layer of the Slavic cultural tradition. It could be seen at two visible levels. The first one was the fact that most likely the language of the Danubian Slavs was used and developed and apparently became the main communication language of the Avar Khaganate ${ }^{80}$. The second tradition with a normative impact might have been the «Slavic» fashion, i.e. the Slavs' typical way of dressing, which was mentioned in a source for the first time. Sicharius, the envoy of the Frankish king Dagobert, had to dress according to the Slavic custom (ad instar Sclavinorum) when he wanted to visit the court of the «king of the Slavs», Samo, as chronicler Fredegar reports ${ }^{81}$. Due to the lack of additional relevant direct sources, historical science has not been able to entirely evaluate the significance that for the further development of the conceptual and consensual Slavic «political» tradition («political imagination») may have had the barbaric kingdom, which the Frankish merchant Samo (623-657) established between the Avar Khaganate and the Frankish Empire. And since a contemporary narrator, namely Fredegar, calls its ruler «King of the Slavs» (rex Sclavinorum), his kingdom necessarily has to be called a «Slavic kingdom».

The formation process of similar political subjects, namely Slavic principalities (kingdoms), at the boundary of the Avar Khaganate did not stop in the following $8^{\text {th }}$ century after the death of Samo. First the written sources tell us about the principality of the Carinthian Slavs ${ }^{82}$. Thanks to the expansion of Charlemagne to Pannonia in the last decade of the $8^{\text {th }}$ century and the enormous effort his successors made to integrate the Slavic territories around the rivers Drava and Sava as well as on both banks of the Danube east of Salzburg in the frame of the newly established pax Francorum, «the peace of the Franks», the sources also mention other political subjects of the Slavs around the Danube. The most important of them were the principalities of the Moravian, the Nitra and the Nitra-Pannonian Slavs in the first half of the $9^{\text {th }}$ century. The unparalleled career of the Moravian principality, most probably under the leadership of the very old dynasty of the Moymirids, culminated in the attractive concept of the «Kingdom of the Slavs», which at a military, political and ecclesiastical level was the achievement of the by Rome and the Empire recognised king of the Slavs, Svatopluk I. Indeed, as the Priest of Dioclea reports, he was «crowned according to the custom of the Roman kings» ${ }^{83}$.

4) It was precisely Svatopluk's political concept of the «Kingdom of the Slavs» as an integral part of the Western Christendom under the aegis of Roman popes and emperors -

\footnotetext{
${ }^{79}$ Ibid.

${ }^{80}$ Curta F. The Slavic lingua franca: Linguistic Notes of an Archeologist Turned Historian // East Central Europe. 2004, Vol. 31. No. 1. P. 125-148.

${ }^{81}$ Fredegarii Chronica, IV, 68 (MGH. Scriptores Rerum Merovingicarum. Vol. 2. Hannover, 1888. P. 154).

${ }^{82}$ Conversio Bagoariorum et Carantanorum: das Weißbuch der Salzburger Kirche über die erfolgreiche Mission in Karantanien und Pannonien mit Zusättzen und Erganzungen / Ed. by H. Wolfram, 2012.

${ }^{83}$ See more details in Homza M., et al. Svätopluk v európskom písomníctve: Štúdie z dejín svätoplukovskej legendy. Bratislava, 2013. P. $127 \mathrm{ff}$.
} 
whose echo shows in the widely spread and variable «Svatopluk's legend» — that became the theme of numerous political derivations in the following centuries ${ }^{84}$. Unlike any previous Slavic tradition, the legend of this invincible king, recognised by Pope Stephen V and Emperor Charles III the Fat - the unifier of the Slavs - spread not only orally, but was also recorded in writing in many places around Europe (and most probably at the court of Svatopluk I himself, too). Thanks to the fact that it was recorded in writing, it gave a new quality to the perception and construction of a common «Slavic cultural memory». In several different versions, the «legend of Svatopluk» was known at all contemporary courts of «Slavic» monarchs east of the Elbe - which can also be attributed to the formative power of the example of Svatopluk ${ }^{85}$.

The unfulfilled attractiveness of Svatopluk's concept of the «Kingdom of the Slavs» between the Byzantine Empire and the restored Latin Empire in the West constituted a challenge for each new generation of «Slavic» political representations in this geopolitical area. In this respect, it is remarkable that besides the local memory bearers, also the Roman popes promoted it. For them, the concept of Svatopluk's Regnum Sclavorum became a kind of counterweight to the Regnum Theutonicorum of the powerful and influential Eastern Frankish rulers, heirs of Charlemagne's imperial title. No wonder, then, that the Polish Kingdom was most probably established not as a «Polish» but rather as a «Slavic» kingdom, as some contemporary sources report ${ }^{86}$. On the basis of some contemporary records and the later narrative by the anonymous author of the Hungarian-Polish Chronicle, a similar hypothesis can apply for the Hungarian Kingdom, which was, in fact, originally a «Kingdom of the Slavs» before becoming a Pannonian ${ }^{87}$ one and only later got the name by which it eventually became traditionally known: Hungarian Kingdom — Regnum Hungariae / Hungarorum ${ }^{88}$.

${ }^{84}$ See also: Homza M. 14. marec roku 1074 a jeho dôsledky na vývoj Nitrianskeho kniežatstva // Slovenské územie / Ed. by R. Letz. Martin, 2017. P. 45-65.

${ }^{85}$ See more details on the topic: Ibid.

${ }^{86}$ The number of the royal titles granted by the papacy includes the royal title for Boleslas I the Brave, acknowledged by Pope John XIX in 1025, several months before his death, as mentioned by the contemporary author, chaplain of Emperor Conrad II, Wipo of Burgundy († 1048). The information related to the year 1025, in the chapter IX under the title De Bolislao dece Sclavorum («On Boleslas, the duke of Slavs»), as follows: «In the same year (...) Slav Boleslav, duke of Polans, gained royal insignia and royal title unjustly against king Conrad, but his impudence caused his sudden death» (Wipos. Gesta Chuonradi imperatoris, IX (MGH. Scriptores rerum Germanicarum in usum scholarum separatim editi / Ed. B. Harry. $3^{\text {rd }}$ ed. Hanoverae; Lipsiae, 1915. P. 31-32)). On the basis of the testimony of late eastern Frankish annals we can assume that the official wording of Wipo's not clearly defined title was identical with the one that Svatopluk I boasted. It was the title «rex Sclavorum». Mieško II, son of Boleslas the Brave boasted the same title: «Misako, qui iam per aliquot annos regnum Sclavorum sibi contra imperialem usurpabat maiestatem...» (Annales Hildesheimenses / Ed. G. Waitz // MGH in usum scholarum ex MGH recusi. Vol. 8. Hannoverae, 1878. P. 35).

${ }^{87}$ The coins with the inscription PANNONIA and PANONAI left the kings of Hungary Peter Orseolo, Samuel Aba, Andreas I, Bela I, Solomon, Gejza I and Ladislav I. Bela and his son Gejza even as Nitrian princes. See: Steinhübel J. Nitrianske kniežatstvo: Počiatky stredovekého Slovenska. Bratislava, 2004. P. 484.

${ }^{88}$ The first Hungarian archbishop Anastasius (Astric/Astrik?) has the following title in the charter of 4 April 1001: «Anastasius abbas monasterii Sancte Marie Sclavanensis» (Diplomata Hungariae antiquissima. Vol. 1 / Ed. G. Györffy. Budapestini, 1992. P. 21. No. 3). Entire «mystery» concerning the titles which has baffled the many Polish, Czech and Hungarian historians for long, can 
All Western Slavic dynasties became, with no exception, bearers of Svatopluk's Slavic political ambitions. Most probably at some point also the Rurikids did. The switch from Scandinavian dynastic princely names into Slavic names containing elements such as -slav, svat-, - mir, -pluk and rast-, which remind of the dynastic names of the Moymirids, may point in that direction. ${ }^{89}$ The most convincing argument supporting this claim is the statistical spreading of the name Svatopluk at the end of the $11^{\text {th }}$ and beginning of the $12^{\text {th }}$ century, but also in the $13^{\text {th }}$ and following centuries ${ }^{90}$. In fact, by the end of the $13^{\text {th }}$ century the name of Svatopluk appears, as so far known, a total of 20 times in all dynasties east of the Elbe, which makes it the most frequent family name among the ruling lineages of this geopolitical area. Besides the ruling dynasties, there were other bearers of Svatopluk's Slavic tradition at lower hierarchical levels, namely the military and certainly also the ecclesiastical elites, as the Nitra legend of Svatopluk indicates. In fact, at the end of the $11^{\text {th }}$ century, Cosmas - the first chronicler of the Premyslids - heard it in ancient Nitra, the centre of Svatopluk's Slavic Kingdom, and wrote it down ${ }^{91}$.

Thus, the attractiveness of the political concept of Svatopluk's «Kingdom of the Slavs» gradually became one of the foundations of the Slavic political thinking and, therefore, also of the entire Slavic cultural memory, a process that started as early as in the late $9^{\text {th }}$ century. Interestingly, it did not lose any of its intensity even after the failed attempt by the first Piasts to revive it in the first decades of the $11^{\text {th }}$ century. Its renewal was the result of the long and tiresome struggle between the empire and the papacy. It started with the election of Pope Nicholas II in 1059, namely during the temporary weakening of the Roman-German Empire in the mid- $11^{\text {th }}$ century. It eventually became known as the struggle for investiture. This conflict peaked during the papacy of Gregory VII the Great ( $\uparrow 1085)$, the famous author of the treatise Dictatus papae. At this very time, all the until now extant papal bulls to Svatopluk, the ruler of the Moravians and the Slavs, were being copied. However, it was also around this time that the two most important legends of Svatopluk are most likely to have been written, namely Svatopluk's Legend by the Priest of Dioclea and the already mentioned Nitra Legend of Svatopluk by Bohemian chronicler Cosmas ${ }^{92}$.

It remains practically unknown - which has to do with the fact that most scholars have failed to notice and, therefore, pay the necessary attention to it — that highly paradoxically, in central and central-eastern Europe, i.e. in the area of the equally imaginary as real Sclavinia, it was precisely the struggle for investiture that brought about the need to create other entirely new original layers of this «cultural tradition» or new «dynastic memory», namely among

perhaps be easily solved. The Hungarian, or earlier Pannonian Kingdom was in the times before the death of Emperor Otto III understood as the restored «Slavic Kingdom». On the development of the substitution in detail, see Homza M., Balegová J. (ed., transl. and commentary). Uhorskopol'ská kronika: Nedocenený prameň k dejinám strednej Európy. Bratislava, 2009. P. 84-85.

${ }^{89}$ I consider symptomatic that compared to the oldest layer of personal proper names, the themes svät- and -pluk appear in the Rurikid dynasty as well. It could point to potential dynastic ties of the Rurikids with a daughter of Svatopluk I, and/or their political aspirations. Polish ruler, Mieszko I, proceeded in a similar way when he gave his son an ambitious name Svätopluk.

${ }^{90}$ See, for example: Urbańczyk P. Co się stało w 965 roku? Poznań, 2016.

${ }^{91}$ See the chapter: Homza M. et al. Svatopluk v európskom písomníctve... P. 89-101.

${ }^{92}$ Homza M. 14. marec roku 1074... P. 45-65. 
those lineages that originally tried to build on the political ideological legacy of Svatopluk ${ }^{93}$. In this investiture conflict, which had an impact on the whole of Europe, these new lineages not only justified their right to rule, but also gained unexpected prestige, from which they drew political credit in the centuries to come. The first «legitimising works»-gesta or «heroic deeds» of the lineages we know as the Premyslids, the Piasts and the Rurikids were written by the official «creators and promoters» of their ideology, i.e. Cosmas, Gallus the Anonymous and Nestor the Chronicler, respectively. All of the mentioned literary attempts by these lineages including the lost gesta or deeds of the Nitra Arpadians - besides their intention to legitimise the power of the new dynasty by sacralising its roots, had another specific «undertone». It was mainly meant to «draw a veil» over their common Svatopluk and Slavic memory. The newly fabulated dynastic memory of these lineages, which most likely owed their previous success to their dynastic ties with the Moymirids ${ }^{94}$, gradually became the antitheses to the very universal idea of Svatopluk's «Slavic province» (Sclavinia) or «Slavic Kingdom», which for a long time remained one of the major allegoric figures in the ideal concept of the restored Latin Roman Empire acknowledged by the Holy See in Rome. At an ecclesiastical-legal level and following this line, the Slavic province of St. Methodius was replaced with the new archbishoprics of Ostrihom/Esztergom and Gniezno around the year 1000. The renovatio imperii the circle of intellectuals around Emperor Otto III and the second bishop of Prague, St. Adalbert, strived for within this frame, was planned to consist of 4 equal provinces. Besides Gallia, Germania and Italia, Sclavinia, i.e. the «Slavic province» = «Slavic Kingdom» was not to be missing.

Therefore, more than innovating the political system leading towards a universal Latin Europe, this plan obviously aimed at updating the original concept of the arrangement of the West, an idea forged 100 years earlier, i.e. around $884-885$ by the common efforts of Emperor Charles III the Fat, the first king of the Slavs Svatopluk I the Great, and Pope Stephen $\mathrm{V}^{95}$. Otto III's efforts to create a universal Europe, which counted with the restoration of the Slavic Kingdom as a counterweight to the German Kingdom - but also in accord with it - were by no means the last attempt to make this political concept come true. Its imperishable clarity emerged again and again whenever the political elites of East-Central Europe needed and were ready to overcome those piteous particularisms that eventually led to the political fragmentation of the territories that were once ruled by the most powerful of the Moymirids, i.e. Svatopluk I. No doubt, the efforts carried out by the emperors of the restored Roman (Roman-German) Empire concerning the political arrangement of power following the death of Otto III in 1003 played a significant role in the fact that the local and dynastic fragmentarisation of «Svatopluk's Slavic political heritage» became fixed in the consciousness of the society - and of present-day historians as well. For them, the idea of a powerful

${ }_{93}$ Homza M. Hranice Nitrianskeho vojvodstva (kniežatstva) v pol'ských stredovekých kronikách // Nitra v slovenských dejinách / Ed. by R. Marsina. Martin, 2002. P. 65-78.

${ }^{94}$ See argumentation in: Homza M. Stredná Európa... P. $105 \mathrm{ff}$.

${ }^{95}$ Fried J. Otton III i Bolesław Chrobry. Warszawa, 2000. - See also: Dvornik F. The Slavs: Their Early History and Civilization. Boston, 1956. P. 256-270; Wolfram H. Around the Year 1000. // Europe Around the Year 1000 / Ed. by P. Urbańczyk. Warszawa 2001. P. 395-399; Homza M. La Grande Moravia tra Oriente e Occidente // I Santi Cirillo e Metodio e la loro eredità religiosa e culturale ponte tra Oriente e Occidente. Raccolta di studi in occasione del $1150^{\circ}$ anniversario della missione dei santi Cirillo e Metodio nella Grande Moravia (863-2013) / Ed. by E. Hrabovec, P. Piatti, and R. Tolomeo. Città del Vaticano, 2015. P. 23-33. 
Slavic kingdom was simply out of question. This is supported, for example, by the fate of the «Slavic crown» from Rome in the case of Boleslas I the Brave, his son Mieszko II, as well as of Boleslas II the Bold/Generous.

From the end of the $10^{\text {th }}$ century onwards and at a local level, the newly established dynasties, in line with their Church hierarchies, aimed at canonising and introducing into their concepts of dynastic memory their own saints (St. Wenceslas in Bohemia, Sts. Boris and Gleb in Rus' or St. Stephen in Hungary), at the expense of the all-Slavic, all-imperial universal saints acknowledged by Rome (such as St. Constantine-Cyril, his brother St. Methodius - the first Slavic archbishop and patron of Sclavinia, St. Vojtech-Adalbert - the second bishop of Prague and martyr). Among other things, the «memory» of these new saints, supported and institutionalised by the Church, was to overlay the previous «memory».

The revival of Svatopluk's concept of Sclavinia was a collateral ideological product of the imperial-papal competition for increased authority. The promotion of the Bohemian Principality to the rank of kingdom is a telling example of this practice. The coronation of the first Bohemian king was preceded by several decades of lobbying by Bohemian princes Spytihnev II $(† 1086)$ and his younger brother Vratislav II ( $\uparrow 1092)$ with the Roman curia. It was connected not only with the efforts of the Bohemian princes to promote the Prague bishopric to the rank of archbishopric, but also with an attempt to free the country from the influence of the Roman-German Empire and its voluntary subordination to the protection of the Roman popes. Like in the previous cases of Svatopluk I's Slavic kingdom and the kingdoms of Croatian Tomislav, Hungarian Stephen I and Polish Boleslas I, the voluntary handover of the country as a feud to the administration of papal authority was carried out in such a way that while Rome sent the royal crown to the north, i.e. to Bohemia, Bohemia sent St Peter's tax southwards, i.e. to Rome. The fact that the crown the Empire was to send to Bohemia was Svatopluk's crown is accurately narrated in the Bohemian tradition, which was preserved in the chronicle of Pribík Pulkava of Radenín, who wrote for Emperor and Bohemian King Charles IV $(\dagger 1378)^{96}$. According to this tradition, the lands that traditionally formed Sclavinia, i.e. Poland and Rus, were subordinated precisely to Svatopluk I, and it was precisely over these lands that the first Bohemian king, Vratislav II, claimed supremacy both practically as well as symbolically. The historical and the legal explanations for his political ambitions, however, resided in the concept of the «Kingdom of the Slavs». Another indication that it was most probably a political concept reaching back to the times of Svatopluk I is a mention in the Pegavian annals according to which Vratislav II was allegedly an offspring of the famous King Boug, whose kingdom once spread as far as the province of Serings (Russes?). In my opinion, this king's name is a shortened form of the name Svatopluk (probably from German Zuendibo(u)lch / Bo(u)lch / Boug). The Czech historical scholarship, on the contrary, would rather identify him as Bohemian prince Boleslas I the $\mathrm{Crue}^{97}$. A counter-argument is found in the writing of the earlier Saxon chronicler, Thietmar of Merseburg, who at the beginning of the $11^{\text {th }}$ century considered Svatopluk I to be a Bohemian ruler ${ }^{98}$. Yet, the superiority of the royal authority of Vratislav II (Wratislaus Primus Rex) over Poland is also emphasised

${ }^{96}$ Přibika z Radenína, řečeného Pulkava. Kronika česká // Kroniky doby Karla IV / Ed. by M. Blahová; transl. by J. Zachová. Praha, 1987. P. 280-281, 306-307. See Annales Pagavienses et Bosovienses / Ed. G. H. Pertz // MGH. Vol. 16. Hannoverae, 1859. P. 236.

${ }^{97}$ See, for example, Wihoda M. První česká království. Praha, 2015. P. 50-52.

${ }^{98}$ Kronika Thietmara / Ed. and transl. by M. Jedlicki. Poznań, 1953. P. 456-457. 
by the first Bohemian chronicler, Cosmas ${ }^{99}$. The so-called Privilege for the Prague Bishopric from 1086 corresponds with this interpretation in the relevant territorial and ecclesiasticaladministrative aspects ${ }^{100}$. There is yet one more argument supporting Svatopluk's political tradition, namely the fact that Emperor Henry IV took advantage of it during the investiture conflict to support Vratislav II. Indeed, Vratislav's younger brother, Otto of Olomouc, duke of a large part of Moravia, had a son called Svatopluk, i.e. Svatopluk I of Olomouc. It was certainly no coincidence, as his wife was Euphemia of Nitra, daughter of Bela I, duke of Nitra and King of Hungary, and sister of other dukes of Nitra and of the Hungarian kings Gejza (Geza) I and Ladislas I. It is no secret either that at the Battle of Mogyoród on 14 March 1074, Otto of Olomouc, together with Gejza I and Ladislas I fought against the Empire ${ }^{101}$.

Therefore, the coronation of Vratislav II and some other later Bohemian kings can be seen as an example of the formulation of Svatopluk's Slavic imperial antithesis. Its objective was to weaken the conceptual force of Svatopluk's universal Slavic legacy, which was at the same time formulated by the papacy. For it is well known that the political prestige of the lineage of imperial margraves and Slavic princes increased in the last decades of the $11^{\text {th }}$ century at the service of the eastern Frankish (German) kings and Roman emperors precisely in the struggle against the papacy, which, on the contrary, in the long term supported the Svatopluk like idea of a powerful «Slavic kingdom». In 1085, Bohemian prince Vratislav II obtained the royal crown ad personam from the excommunicated Emperor Henry IV († 1106). His grandson Vladislav II († 1172) also obtained the crown from an Emperor, namely Frederick Barbarossa, but it was as late as $1158^{102}$. To be accepted among the European ruling elite, the Bohemian princes lacked the necessary dose of royal blood, but the Premyslids managed to obtain it by means of successful marriage ties with some Hungarian princesses.

As it has already been indicated, the conceptual (literary) background necessary for the steep rise of the Premyslids was prepared by their conscientious Cosmas of Prague in his Chronicle of the Bohemians, which in fact describes the deeds (gesta) of the descendants of the legendary Premysl the Ploughman, whose story he first thoroughly elaborated in his mind. Understandably, he could not completely avoid the tradition of Svatopluk's «Slavic kingdom». He dealt with it in his typical narrative way: by having Svatopluk simply «disappear» («in the middle of his troops») and the first Bohemian and, more or less legendary, prince Bořivoj baptised in the same year ${ }^{103}$.

However, the new «particularist» dynasties between the Elbe and the Dneper (and later the Volga, too) could hardly compete in the long run with the universalism of Svatopluk's concept of a «Slavic kingdom». The most significant example is Emperor Charles IV of Luxembourg in the $14^{\text {th }}$ century, who, metaphorically, resembled more Svatopluk I than Charlemagne ${ }^{104}$.

${ }_{99}$ Cosmae, Pragensis. Chronica Boemorum / Ed. B. Bretholz (MGH. Scriptores Rerum Germanicarum. Nova Series. Vol. 2. Berlin, 1923. P. 141).

${ }^{100}$ Ibid. P. 138; Codex diplomaticus et epistolaris Slovaciae. Vol. 1 / Ed. R. Marsina. Bratislava, 1974. P. 58-59.

${ }^{101}$ Homza M. 14. marec roku $1074 . .$. , passim.

${ }^{102}$ Wihoda M. První česká království..., passim; Mašek M., Sommer P., Žemlička J.; et al. Vladislav II.: druhý král z Přemyslova rodu: k 850. výročí jeho korunovace. Praha, 2009.

${ }^{103}$ See the chapter: Homza M., et al. Svätopluk v európskom písomníctve... P. 89-101.

${ }^{104}$ See: Homza M. Back to the Subject of the Royal Title of Svätopluk I, or Reply to Ján Steinhübel and Other Present and Past AntidicoSvätoplukians // Slovak Studies. 2016. No. 1-2. P. $160-186$. 
In his struggle to push through the values and objectives of the universal Roman legacy, this new Svatopluk (Charles IV) did not hesitate to use yet another emblem of the in the late Middle Ages already well-developed Slavic cultural tradition, i.e. the spiritual legacy of St. Constantine (Cyril) and the first archbishop of the Slavs, his brother St. Methodius.

5) My analysis has now reached its final point. In my opinion, more than all the political and religious elites of the Slavs, their dynasties, King Svatopluk I, all medieval narrators and after them all Slavic writers of the following centuries, it was precisely St. Constantine (Cyril) who contributed the most to the quality of the «Slavic cultural memory», especially of its «formative» and «normative» aspects, in short, to the timeless definition of the vis of the name Slav.

St. Methodius, his brother, and his (their) disciples «just» had to «institutionalize» this memory. First, by establishing a Slavic archbishopric acknowledged by Rome, and then by transferring it to the framework of the newly established Bulgarian Empire. In this way, the saint brothers from Thessaloniki managed to create not only an attractive but also an unbelievably exclusive and - in any case - very consequent and complex concept of Slavdom. Thanks to its unusual intellectual depth, this cultural-religious concept of Slavdom has not lost any of its validity until today.

While the Moravian duke Rastislav is generally considered to be the commissioner (conductor operarum) of the Life of St. Constantine; the later Life of St. Methodius has both, Svatopluk and Rastislav, in this role. The anonymous author of the passage «On the translation of the books» in the Russian Primary Chronicle adds Kocel' of Nitra-Pannonia to them. At the same time he also gives Kocel' (quite rightfully) the credit for the creation of a Slavic province with its centre in the ancient Roman Sirmium (currently Sriemska Mitrovica in Serbia), which would eventually play a key role in many aspects. However, concerning the question of the «invitation» of the Thessaloniki brothers to Moravia, I am more inclined to believe that this whole initiative - or at least its core - came from St Constantine himself ${ }^{105}$.

The motif which gave origin to the new and exceptionally semantically loaded definition of Slavdom was an immanent element of St. Constantine the Philosopher himself. Indeed, it is sufficiently explained in the introduction to the Life of St Constantine and also in the poem Proglas, which unanimously put the deed of St Constantine in direct relation to the acts that in the history of salvation initiated the Holy Spirit. There are various arguments to support this hypothesis. However, the most important of them is, certainly, the mere intention of the in many aspects revolutionary work of St. Constantine. It is obvious that the intended audience was intentionally limited to those who can read the bukvy, the revealed and, therefore, sacred Slavic letters ${ }^{106}$, i.e. the glagolitic, later cyrillic alphabet. These people were basically just the pupils of St. Constantine the Philosopher. Interestingly, according to the Life of St. Constantine, the first worldly dignitary to learn this alphabet was Prince Kocel' in Blatnohrad. The Life

${ }^{105}$ Homza M. Niekol'ko slov k dialógu svätého Konštantína Filozofa s Agarénmi (Saracénmi)a otázke chápania vojny v ňom // Vojna a vojenstvo v práve: Zborník z medzinárodnej vedeckej konferencie, konanej dňa 5. 11.2015 v Bratislave / Ed. by A. Letková, M. Lysý, and M. Považan. Bratislava, 2016. P. 27-44.

${ }^{106}$ In oder to understand the moment of «revelation of Slavic letters» it is necessary to consider the fact that earlier sets of letters, such as Hebrew, Latin, and Greek scripts, were considered as negatively loaded and thus imperfect in one way or another from the viewpoint of the revelation of the Gospel of Jesus Christ. 
of St. Constantine and later other literary works and translations were above all meant for them. The poem Proglas, however, does not hide St Constantine's ambition to spread among all Slavs his «gift», i.e. the new system of identification signs that create a special, unusually religious and culturally deeply anchored «Slavic cultural tradition». Indeed, his work Proglas clearly reads «Alas, hear, hear this, Slavs» («Того же ради сльиште, Словгне, си»).

The creation of the Slavic letters or «bukvy» and the Slavic writing or «gramota», was the first step towards achieving this goal. It had two major functions.

The first one is obvious from the outside. Once the formal coding and decoding, i.e. writing and reading in this sign system - which by the way is congenial at all levels - has been mastered, first comes the encounter, then the integration and finally the mutual identification of those who use the Slavic system to write and read. In other words, those who write, read, and understand the Slavic «bukvy» and «gramota», «become» Slavs by mastering this system. In the narrative «On the translation of the books», which in my opinion renders the personal experience of the person writing these letters, its unknown author clearly relates together the invention of the Slavic letters, with the consciousness and the language of the Danubian Slavs ${ }^{107}$ and the Russes (Polyanians). The anonymous author of the identification construction Russes $=$ Slavs explains it as follows: $«$ But the Slavs and the Russes are one people, for it is because of the Varangians that the later become known as Rus', though originally they were Slavs. While some Slavs were termed Polyanians their speech was still Slavic, for their were known Polyanians because their lived in the fields. But they have the same Slavic language ${ }^{108}$.

Activating the second function is a more complex process. It requires not only to formally master the Slavic writing system, but also to understand the meaning of the words presented in this language in writing as well as orally. Let me remind at this point that these letters were not revealed to St. Constantine for pragmatic and economic reasons, which was, in fact, the direct cause for the apparition of all previous and later graphic systems capturing the human speech, but - instead - for religious and cultural reasons. St. Constantine the Philosopher, the author and initiator of the introduction of the new Slavic writing system and the new sacred language (Old Church Slavonic) based on this system, could — and is very likely to - have had a hidden ambition, namely to understand the Gospel in its closest possible form to its real content. This would, in fact, explain the unusual complementarity of the newly introduced «Slavic paradigm».

The causa scribendi of two basic literary works, which can be justifiably attributed to St. Constantine, namely Proglas and the Life of St. Constantine, lies somewhere here. Both texts explain the main reasons why the Slavic cultural tradition was given a new quality. The Life of St. Constantine, just like the poem Proglas, were to serve as the collection of the most important questions - themes and replies to the arguments the defenders, promoters and mediators of the new, written Slavic form of the «normative Slavic cultural memory» could be confronted with when transmitting it. That is why the the Life of St. Constantine and Proglas have always been fundamental for the formation of the new stage of the «Slavic

107 The Prologue of the Russian Primary Chronicle contains this mention about Slavic letters: «И тако разидеся словъньский языкъ, тђм же и грамота прозвася словьньская» (ПВЛ. C. 8, 144).

${ }^{108}$ The Russian Primary Chronicle... Р. 63. «А словеньскый языкъ и рускый одно есть, от варягъ бо прозвашася Русью, а первое бъша словене; аще и поляне звахуся, но словеньская рьчь бъ. Полями же прозвани быши, зане в поли сьдяху, а язык словенски един» (ПВЛ. С. 16). 
cultural tradition» in many respects. At the same time they constitute the starting point for any reception and perception of Slavdom in the future. The Life of St. Constantine and Proglas can namely be defined as the basic ideational paradigm of the specific Slavic interpretation of Christendom in the history of the universal Church.

St Constantine the Philosopher, his brother St Methodius and their pupils also contributed in other ways to defining the original «Slavic cultural memory». Besides the original «letters inspired by the Holy Spirit», the translation of the Bible and other books needed to carry out different everyday pastoral activities, of ecclesiastical and worldly law-books and distinctive Slavic literature, it is necessary to attribute to St. Constantine or to one of his disciples the authorship in the construction of the Slavic narrative origo gentis. The account «On the translation of the books», which forms the first pages of the Russian Primary Chronicle already presents some connections between the Old Testament story of the confusion of languages at the tower of Babel and the Danubian Slavs, as well as between the sons of Japhet and the first Slavs in Pannonia and Noricum. As already suggested, it is very likely to have been written at the court of Prince Kocel' in Blatnohrad before 876. The anonymous author of this ideal, just like the author of the Life of St. Constantine, does not hide his admiration for this ruler. It was Kocel"s castle near the present-day Hungarian town of Zalavár, which in a very short time - towards the end of the 860s and the beginning of the 870s - became the place from which the energy of a new Slavic appeal literally «radiated» in all directions. St. Constantine the Philosopher, his brother Methodius and a circle of scholars (including Kocel' himself), by connecting Slavdom with the Old Testament, provided the necessary ecclesiastical justification for their work, based on the return of the «confused» descendants of Japheth, son of Noah, to the path of salvation. Moreover, with the following Biblical quotation: «May God enlarge Japheth, and let him dwell in the tents of Shem, and let Canaan be his servant» (Gn. 9:27) they also placed the Japhethites (Slavs) at the very centre of the future political and spiritual history of the world ${ }^{109}$. This also explains the unusual emphasis, which the author of the Life of St. Constantine gives the argumentation of St. Constantine in his debate with the Khazars (Jews).

The author of the Life of St. Constantine stresses his intention - to show the superiority of his system over other, similar, older and younger systems - at several places. Let me mention, for example, the seemingly accidental remark on the fact that Constantine first translated the Gospel of John into the new language and its graphemes, which begins as follows: «In the beginning was the Word, and the Word was with God, and the Word was God...». The sound and graphic connection of the endonym Slav with Greek logos ( $\lambda$ ó $\gamma$ os), that is, «Slovo» (word) and translating the Gospel of John, which starts with the Word, is certainly not accidental. Through this connection, St Constantine the Philosopher created a new "semantic field» between the figure of St John and the — I believe — at that time already planned (in his mind at least) distinctive Slavic Church. In this respect, as one can read in the Gospel of John $(21,23)$ Christ declared «...So I will have him to remain till I come». Vladimir Toporov

${ }^{109}$ Kohut Z. E. From Japheth to Moscow: Narrating Biblical and Ethnic Origins of the Slavs in Polish, Ukrainian, and Russian Historiography (Sixteenth-Eighteenth Centuries) // Journal of Ukrainian Studies. 2008-2009. Vol. 33-34. P. 27-29. 
formulated this almost eschatological definition of Slavdom in a mythogem of the Slavs «Slavs, the people of the Word» ${ }^{110}$.

Slavdom defined in this way becomes more than a matter of the past or the present. It is a matter of the future. It has not become yet, but it is to become. It is meant to become (at least in the understanding of St Constantine the Philosopher) a formative force, which has a predestined task in the history of mankind. It was perhaps while contemplating this idea of the Life of St. Constantine that Vladimir Sergeyevich Solovyov - who seems to have found inspiration in Constantine the Philosopher in other themes as well - sketched his «elder John», a representative of the Slavic Church at the last ecumenical council, of whom they said «he is the real old John, that is, St. John the Evangelist, who allegedly... did not die but appeared now at the end of times», the representative of the Orthodox believers in the Short legend about the Antichrist. He has elder John utter the following words: «My sons, this is the Antichrist». With these words, the old man was the first to unmask the «great man of the $21^{\text {st }}$ century», the first emperor of united mankind at the council. Through this «disclosure» he also pointed out the many dangers of the current civilisation, which «prefers life to the being» and exalts man above God. No matter how speculative this understanding of the future function of Slavdom may appear, one thing is clear - also this view forms part of the broad spectrum of vis the Slavic identity has had from its beginning until the present days.

The above listed theses show that the Slavic identity has several, in the course of history defined cultural layers, all of which have their particular features. Its starting points resemble other «barbarian» identities of male military communities from the time of the crisis and partial collapse of the Roman Empire around the $5^{\text {th }}$ century. In the last decades of the $9^{\text {th }}$ century, two almost parallel events played a significant role in the definition of its new form, which had already been recorded in writing. On the one hand, there are the efforts carried out by Svatopluk I the Great to unite all Slavs into a higher political unit (the «Slavic Kingdom») as an integral part of the «restored» Roman Empire of the Western Latin universe under the aegis of Roman popes and emperors. In the course of history there have been several attempts to make this idea come true. Nevertheless, the Slavs east of the river Elbe have not managed to fulfil this political objective so far. The successful political unification attempts of the Italians and the Germans in the last third of the $19^{\text {th }}$ century remain an inspiration for them in many ways. On the other hand, St Constantine the Philosopher, his brother St Methodius, the first archbishop of Slavs, and their holy disciples filled the identity of the Slavs (the people of the Word) with an innovative and, thus, unusually attractive Christian religious and cultural content. Besides the Latin and Greek forms of Christianity, Judaism and Islam, they laid the foundations of an unusually viable «Slavic Church» and a «Slavic written heritage», whose limits are still to be entirely and fully explored.

Данные о статье

Автор: Хомза, Мартин - доктор истории, профессор, Университет им. Я. А. Коменского, Братислава, Словакия, martin.homza@uniba.sk

Заголовок: Несколько слов об идентичности славян, вчера, сегодня и завтра.

Резюме: В статье обобщены итоги многолетних размышлений автора о происхождении славян, славянской идентичности и ее успешном распространении в Средние века. Автор отмечает, что хотя вопрос о пост-римской социальной самоидентификации десятилетиями обсуждался не только

${ }^{110}$ Топоров B. Н. Святость и святые в русской духовной культуре. Т. I: Первый век христианства на Руси. М., 1995. С. 19-67. 
в Европе, но и во всем мире, более глубокого понимания того, как появилась и распространилась славянская идентичность, так и не было достигнуто. По мнению автора, успех славянской идентичности был обусловлен качественностью и привлекательностью славянской культурной памяти, в эволюции которой наблюдаются три основные фазы, последовавшие за важной отправной точкой, каковой было революционное решение воинского сообщества, образовавшегося на Нижнем и Среднем Дунае, принять имя славян. Первой фазой было формирование культурной памяти, которая, так же, как и других варварских воинских сообществ (gentes), образовавшихся после падения Римской империи, была построена на литературной (устной) передаче традиции, повествовавшей о славных деяниях сообщества и его элиты (правителя, династии, дружины). Вторая и третья фазы развития славянской идентичности относятся к исторически относительно краткому периоду существования Великой Моравии, начинаясь и заканчиваясь в IX в. На политическом уровне увеличившаяся привлекательность концепции самоидентификации славянских элит привела к масштабной территориальной экспансии страны дунайских славян во время правления Святополка I и формальному образованию «Славянского королевства», которая было признано как Римом, так и Империей. На культурном уровне, однако, успех династии Моймировичей был превзойден миссионерской деятельностью св. Константина Философа и его брата Мефодия, которые изобрели славянскую азбуку и славянский литургический язык, перевели Священное Писание, создали некоторые оригинальные литературные произведения и т. д. Автор рассматривает основанную на сближении названия «словене» с понятием «Логос», то есть «Слово», христианскую концепцию самоидентификации славян, которая была разработана св. Кириллом и стала nomen est omen применительно к прошлому, настоящему и будущему славян.

Ключевые слова: славяне, славянская идентичность, Великая Моравия, Кирилл и Мефодий.

Литература, использованная в статье:

Крадин, Николай Николаевич. Кочевники Евразии. Алматы: Даук-пресс, 2007. 416 с.

Литвина, Анна Феликсовна; Успенский, Федор Борисович. Выбор имени у русских князей X-XVI вв. Династическая история сквозь призму антропонимики. Москва: Индрик, 2006. 904 с.

Свердлов, Михаил Борисович. К истории великоморавской культурной традиции на Руси конца XI начала ХІІ в. // Петербургский исторический журнал. 2015. Вып. 7. № 3. С. 10-21.

Флоря, Борис Николаевич. Сказание о преложении книг на словенский язык: Источники, время и место написания // Byzantinoslavica. 1985. Vol. 46. No. 1. Pp. 121-130.

Abrams, Lesley. Diaspora and Identity in the Viking Age // Early Medieval Europe. 2012. Vol. 20. Pp. 17-38. Assman, Jan. Collective Memory and Cultural Identity // Cultural History / Cultural Studies. 1995. Vol. 65. Pp. 125-133.

Avenarius, Alexander. K problematike avarskoslovanského vzt'ahu na dolnom Dunaji v 6.-7. stor. // Slovanské štúdie. 1971. Vol. 11. Pp. 223-244.

Avenarius, Alexander. Die Awaren in Europa / Transl. by Nováková, Uršula. Amsterdam; Bratislava, 1974. $283 \mathrm{p}$.

Avenarius, Alexander. Začiatky Slovanov na strednom Dunaji: autochtonistická teória vo svetle súčasného bádania // Historický časopis. 1992. Vol. 40. № 1. Pp. 1-15.

Barford, Paul. The Early Slavs: Culture and Society in Early Medieval Eastern Europe. London: British Museum Press, 2001. 416 p.

Brather, Sebastian. Ethnische Interpretationen in der frühgeschichtlichen Archäologie: Geschichte, Grundlagen und Alternativen. Berlin; New York, Walther de Gruyter Publ., 2004. 807 p.

Brather, Sebastian. The Archaeology of the Northwestern Slavs (Seventh To Ninth Centuries) // East Central Europe. 2004. Vol. 31. No. 1. Pp. 78-81.

Brown, Elizabeth. Myths Chasing Myth: The Legend of the Trojan Origin of the French and its Dismantling // The Man of Many Devices, who Wandered full Many Ways... : Festschrift in Honor of János M. Bak / Ed. by Nagy, Balász; Sebők, Marcell. Budapest, CEU Press, 1999. Pp. 613-633.

Curta, Florin. The making of the Slavs. History and archaeology of the Lower Danube Region, c. 500-700. Cambridge: Cambridge University Press, 2001. 436 p.

Curta, Florin. From Kossina to Bromley — Ethnogenesis in Slavic Archeology // Barbarian Identity: Critical Approaches to Ethnicity in the Early Middle Ages / Ed. By Gillett, Andrew. Turnhout: Brepols, 2002. Pp. 201-218.

Curta, Florin. The Slavic lingua franca: Linguistic Notes of an Archeologist Turned Historian // East Central Europe. 2004, Vol. 31. No. 1. Pp. 125-148. 
Curta, Florin. The Making of the Slavs: Slavic Ethnogenesis Revisited // MESS and RAMSES II. Mediterranean Ethnological Summer School. Vol. 7. Ljubljana: Znanstvena založba Filozofske fakultete, 2008. Pp. 277-307.

Dostálová, Růžena. Byzantská vzdělanost. Praha, Vyšehrad Publ., 1990. 416 p.

Dvornik, Francis. The Slavs Their Early History and Civilization. Boston, American Academy of Arts and Sciences Publ., 1956. 394 p.

Dzino, Danijel. Becoming Slav, becoming Croat: identity transformations in post-Roman and early medieval Dalmatia. Leiden: Brill, 2010. 272 p.

Ďurina, Lubomír. Malá knižná reminiscencia // Proglas. 1999. Vol. 10. No. 2. Pp. 11-14.

Fried, Johannes. Otton III i Bolesław Chrobry / Transl. by Kaźmierczak, Elżbieta; Leder, Witold. Warszawa, Wiedza Powszechna Publ., 2000. 270 p.

Geary, Patrick. Ethnic Identity as a Situational Construct in the Early Middle Ages // Mitteilungen der anthropologischen Gesellschaft. 1983. Vol. 113. Pp. 15-26.

Geary, Patrick. The Crisis of European Identity Barbarian Ethnicity and Identity // From Roman Provinces to Medieval Kingdoms / Ed. By Noble, Thomas. London; New York: Routledge, 2006. Pp. 27-34.

Geary, Patrick. Barbarians and ethnicity // Interpreting late antiquity: Essays on the postclassical world / Ed. By Bowersock, Glen Warren; Brown, Peter; Grabar, Oleg. London, Belknap Press, 2001. Pp. 107-129. Graus, František. Raně středověké družiny a jejich význam při vzniku států ve střední Evropě // Československý časopis historický. 1965. Vol. 13. No. 1. Pp. 1-18.

Homza, Martin. Niekol'ko téz k počiatkom slovenského etnika // Studia Academica Slovaca. 2002. Roč. 31. S. 285-295.

Homza, Martin. Uhorsko-pol'ská kronika: nedocenený prameň k dejinám strednej Európy. Bratislava, Post Scriptum Publ., 2009. 223 p.

Homza, Martin. Stredná Európa I. Na začiatku stredoveku. Bratislava, Comenius University Publ., 2014. $313 \mathrm{p}$.

Homza, Martin. La Grande Moravia tra Oriente e Occidente // I Santi Cirillo e Metodio e la loro eredità religiosa e culturale ponte tra Oriente e Occidente. Raccolta di studi in occasione del $1150^{\circ}$ anniversario della missione dei santi Cirillo e Metodio nella Grande Moravia (863-2013) / Ed. by: Hrabovec, Emilia; Piatti, Pierantonio; Tolomeo, Rita. Città del Vaticano: Libreria Editrice Vaticana Publ., 2015. Pp. 23-33.

Homza, Martin. Back to the Subject of the Royal Title of Svätopluk I, or Reply to Ján Steinhübel and Other Present and Past AntidicoSvätoplukians // Slovak Studies. 2016. No. 1-2. Pp. 160-186.

Homza, Martin. Niekol'ko slov k dialógu svätého Konštantína Filozofa s Agarénmi (Saracénmi)a otázke chápania vojny v ňom // Vojna a vojenstvo v práve: Zborník z medzinárodnej vedeckej konferencie, konanej dňa 5. 11.2015 v Bratislave / Ed. by: Letková, Alexandra; Lysý, Miroslav; Považan, Michal. Bratislava, Univerzita Komenského, 2016. Pp. 27-44.

Homza, Martin. 14. marec roku 1074 a jeho dôsledky na vývoj Nitrianskeho kniežatstva // Slovenské územie / Ed. by: Letz, Róbert. Martin, Matica slovenská, 2017. Pp. 45-65.

Homza, Martin. Hranice Nitrianskeho vojvodstva (kniežatstva) v pol’ských stredovekých kronikách // Nitra v slovenských dejinách. Martin, Matica Slovenská Publ., 2002. Pp. 65-78.

Homza, Martin; et al. Svätopluk v europskom pisomnictve. Studie z dejin svatoplukovskej legendy. Bratislava, Post Scriptum Publ., 2013. 749 p.

Homza, Martin; Rácová, Nad'a. K vývinu slovenskej myšlienky do polovice 18. storočia. Bratislava, Stimul Publ., 2010. 275 p.

Horák Antonín. O Slovanech úlně jinak: Co nebylo o Slovanech dosud. Vizovice: LÍPA Publ., 1991. 318 p. Hromnik, Cyril. Sloveni a Slovensko. Martin, Matica slovenská, 2015. 928 p.

Hurbanič, Martin. Posledná vojna antiky: Avarský útok na Konštantínopol roku 626 v historických súvislostiach. Prešov, Michal Vlaško Publ., 2009. 377 p.

Jones, Siân. The Archaeology of Ethnicity: Constructing identities in the past and present. London, Routledge Publ., 1997. 200 p.

Kohut, Zenon. From Japheth to Moscow: Narrating Biblical and Ethnic Origins of the Slavs in Polish, Ukrainian, and Russian Historiography (Sixteenth-Eighteenth Centuries) // Journal of Ukrainian Studies. 2008-2009. Vol. 33-34. Pp. 27-292.

Králik, Lubor. Stručný etymologický slovník slovenčiny. Bratislava, VEDA Publ., 2015. 704 p.

Máčala, Pavol. Etnogenéza Slovanov v archeológii. Košice: Slovo Publ., 1995. 96 p. 
Malinovská, Nora. Geographical concepts of Sclavinia in historical sources from the sixth to the fourteenth century, with an emphasis on the Moravian-Pannonian and South Slavic tradition // Slovakia and Croatia. Historical parallels and connections (until 1780) / Ed. by Homza, Martin etc. Bratislava; Zagreb: Department of Slovak history, Faculty of Philosophy of the Comenius University, Bratislava; Faculty of Philosophy of Zagreb University, 2013. Pp. 60-65.

Malinovská, Nora. Vývoj koncepcie Sclavinia v 12. storočí a jej reflexia v pol'skej kronike Galla Anonyma // Nové historické rozhl'ady. 2015. Vol. 5. No. 1. Pp. 43-53.

Mašek, Michal; Sommer, Petr; Žemlička, Josef; et al. Vladislav II.: druhý král z Přemyslova rodu: k 850. výročí jeho korunovace. Praha: Nakladatelství Lidové noviny, 2009. 259 s.

Mesiarkin, Adam. Examining the Slavic identity in Middle Ages // Studia Ceranea. 2013. Vol. 3. Pp. 83-100. Mesiarkin, Adam. The Basis of Research into Croatian and Slovak Ethnogenesis // Slovakia and Croatia. Historical parallels and connections (until 1780) / Ed. by Homza, Martin, etc. Bratislava; Zagreb, Department of Slovak history, Faculty of Philosophy of the Comenius University, Bratislava: Faculty of Philosophy of Zagreb University, 2013. Pp. 38-42.

Mesiarkin, Adam. Veča príspevok k dejinám slovanského práva // Historický časopis. 2016. Vol. 64. No. 2. Pp. 333-360.

Montinaro, Federico. Byzantium and the Slavs in the Reign of Justinian: Comparing the Two Recensions of Procopius's Buildings // The Pontic-Danubian Realm in the Period of the Great Migration / Ed. by Ivanišević, Vujadin; Kazanski, Michel. Paris; Belgrade: Peeters Publ., 2011. Pp. 89-114.

Plassmann, Alheydis. Origo gentis: Identitäts und Legitimitätsstiftung in früh- und hochmittelalterlichen Herkunfterzählungen. Berlin, Akademie Publ., 2006. 458 p.

Podolan, Peter. Aspekty slovenskej historiografie generácie Jána Kollára a Pavla Jozefa Šafárika // Forum Historiae. 2007. Vol. 1. Pp. 1-13.

Podolan, Peter. Odkaz Jána Kollára slovenskej historiografii // Historia Nova. Vol. II: Štúdie k jubileu Pavla Jozefa Šafárika. Bratislava, 2011. Vol. 5. Pp. 43-51.

Pohl, Walter. Die Awaren: ein Steppenvolk in Mitteleuropa, 567-822 n. Chr. München, Beck Publ., 1988. $553 \mathrm{p}$.

Pohl, Walter. Telling the difference: Signs of ethnic identity // From Roman Provinces to Medieval Kingdoms / Ed. by Noble, Thomas. London; New York: Routledge, 2006. Pp. 99-138.

Pohl, Walter. Początki Słowian: Kilka spostrzeżeń historicznych // Nie-Słowianie o początkach Słowian / Ed. by Urbańczyk, Przemysław. Poznań, Poznańskie Towarzystwo Przyjaciół Nauk Publ., 2006. Pp. 11-27. Pohl, Walter. Staat und Herrschaft im frühen Mittelalter: Überlegung zum Forschungstand // Staat im frühen Mittelalter / Ed. by Stuart, Airlie; Pohl, Walter; Reimitz, Helmut. Wien, Austrian Academy of Sciences Publ., 2006. Pp. 9-38.

Pritsak, Omeljan. The Slavs and the Avars // Settimane di studio del centro italiano di studi sull'alto medioevo. Vol. XXX: Gli Slavi occidentali e meridionali nell'alto medioevo. Spoleto, Centro di Studio del Centro Italiano di Studi sull'alto Medioevo, 1983. P. 353-435.

Smith, David. Myths and memories of the nation. Oxford: Oxford University Press, 1999. 288 p.

Timura, Viktor. Zamlčané dejiny: Pôvod a začiatky Slovenov-Slovákov. Bratislava, Eko-konzult Publ., 2015. $504 \mathrm{p}$.

Tyszkiewicz, Lech. Koczownicy turecko-mongolscy a migracje Słowian // Wedrówka i etnogeneza w staroźytności i w średniowieczu / Ed. by Salamon, Maciej; Strzelczyk, Jerzy. Kraków: Historia Iagellonica, 2004. S. 190-210.

Urbańczyk, Przemysław. Władza i polityka we wczesnym średniowieczu. Wrocław, Wrocław University Publ., 2000. 280 p.

Urbańczyk, Przemysław. Co się stało w 965 roku? Poznań, Zysk i S-ka Publ., 2016. 168 p. (in Polish).

Váña, Zdeněk. Svět dávných Slovanů. Praha, Artia Publ., 1983. 239 p.

Verešová, Nora. Vývoj chápania geografického termínu Sklavínia v historických prameňoch 6.-14. storočia // Historický zborník. Martin: Matica slovenská, 2008. No. 1. P. 124-143.

Verešová, Nora. Povest' vremennych let a jej koncepcia Slovienskoj zemli // Historia Nova. Vol. II: Štúdie k jubileu Pavla Jozefa Šafárika. Bratislava, 2011. P. 12-20.

Wenskus, Reinhard. Stammesbildung und Verfassung. Das Werden der frühmittelalterlichen gentes. Köln; Graz: Böhlau Verlag, 1961. 656 p.

Wihoda, Martin. První česká království. Praha, Lidové noviny Publ., 2015. 440 p. 
Wolfram, Herwig. Around the Year 1000 // Europa around the Year 1000 / Ed. by Urbanczyk, Przemysław. Warszawa, DiG Publ., 2001. Pp. 395-399.

Wolfram, Herwig. Origo et religio. Ethnic traditions and literature in early medieval texts // From Roman Provinces to Medieval Kingdoms / Ed. By Noble, Thomas. London; New York: Routledge, 2006. P. 57-74. Wolfram, Herwig. Terminologisches // Nomen und Fraternitas: Festschrift für Dieter Geuenich zum 65. Geburtstag / Ed. by Ludwig, Uwe; Schilp, Thomas. Berlin; New York, 2008. P. 787-802.

Wolfram, Herwig. Conversio Bagoariorum et Carantanorum: Das Weißbuch der Salzburger Kirche über die erfolgreiche Mission in Karantanien und Pannonien mit Zusättzen und Erganzungen. Ljubljana, Hermagoras Publ., 2012. 419 p.

Information about the article

Author: Homza, Martin - Doctor in History, Professor, Comenius University, Bratislava, Slovakia, martin.homza@uniba.sk

Title: A few words about the identity of the Slavs, yesterday, today and tomorrow.

Summary: This paper brings together the considerations that for many years the author has gathered on the origin, identity and successful expansion of the Slavs throughout the world. The author notes that although the issue of post-Roman social self-identification has been discussed for several decades not only in Europe but also worldwide, a deeper understanding of the apparition and expansion of the Slavic identity has not yet been achieved. In the author's opinion, the success of the Slavic identity was the result of the quality and attractiveness of the Slavic cultural memory, whose evolution shows three basic stages following the necessary starting point, i.e. the revolutionary decision taken by the military community at the Low and Middle Danube to adopt the name Slav. The first phase is the formation of their cultural memory, which just like that of other barbarian military communities (gentes) in the aftermath of the fall of the Roman Empire, was built on the literary (oral) transmission of the narrative that told the glorious deeds of the community and its elite (ruler, dynasty, retinue). The second and third stages of the development of the Slavic identity constitute the historically relatively short period of the Great Moravia, beginning and ending in the 9th century. On a political level, the increased attractiveness of the self-identification concept of the Slavic elites resulted in the vastest territorial expansion of the land of the Danubian Slavs during the reign of Svatopluk I and the formal constitution of the Slavic Kingdom, which was recognised by both, Rome and the Empire. On a cultural level, however, the success of the Moymirid dynasty was outperformed by the missionary work of St. Constantine the Philosopher and his brother St Methodius, who created the Slavic alphabet and the Slavonic liturgical language, translated the Sacred Scriptures, wrote some original literature works, etc. The author considers the Christian concept of self-identification, built on the identical wording of the word Logos, i.e. Slovo (Word) and Slovan (Slav) - which was developed by St. Constantine the Philosopher - to have become the nomen est omen of the past, the present and the future of the Slavs.

Keywords: Slavs, Slavic identity, Great Moravia, Sts Cyril and Methodius.

References:

Abrams, Lesley. Diaspora and Identity in the Viking Age, in Early Medieval Europe. 2012. Vol. 20. Pp. 17-38.

Assman, Jan. Collective Memory and Cultural Identity, in Cultural History / Cultural Studies. 1995. Vol. 65. Pp. 125-133.

Avenarius, Alexander. K problematike avarskoslovanského vzt'ahu na dolnom Dunaji v 6.-7. stor. [On the problem of the Avar-Slavic relations in the Lower Danube region], in Slovanské štúdie. 1971. Vol. 11. Pp. 223-244 (in Slovak).

Avenarius, Alexander. Die Awaren in Europa [The Avars in Europe] / Transl. by Nováková, Uršula. Amsterdam; Bratislava, 1974. 283 p. (in Slovak).

Avenarius, Alexander. Začiatky Slovanov na strednom Dunaji: autochtonistická teória vo svetle súčasného bádania [Origins of the Slavs in the Middle Danube region: The autochtonist theory in the light of contemporary research], in Historický časopis. 1992. Vol. 40. No. 1. Pp. 1-15 (in Slovak).

Barford, Paul. The Early Slavs: Culture and Society in Early Medieval Eastern Europe. London: British Museum Press, 2001. 416 p.

Brather, Sebastian. Ethnische Interpretationen in der frühgeschichtlichen Archäologie: Geschichte, Grundlagen und Alternativen [Ethnic Interpretations in Early Medieval Archaeology: History, Basis, and Alternatives]. Berlin; New York, Walther de Gruyter Publ., 2004. 807 p. 
Brather, Sebastian. The Archaeology of the Northwestern Slavs (Seventh To Ninth Centuries), in East Central Europe. 2004. Vol. 31. No. 1. Pp. 78-81.

Brown, Elizabeth A. R. Myths Chasing Myth: The Legend of the Trojan Origin of the French and its Dismantling, in Nagy, Balász; Sebök, Marcell (eds).The Man of Many Devices, who Wandered full Many Ways... : Festschrift in Honor of János M. Bak. Budapest, CEU Press, 1999. Pp. 613-633.

Curta, Florin. The making of the Slavs. History and archaeology of the Lower Danube Region, c. 500-700. Cambridge: Cambridge University Press, 2001. 436 p.

Curta, Florin. From Kossina to Bromley - Ethnogenesis in Slavic Archeology, in Gillett, Andrew (ed.). Barbarian Identity: Critical Approaches to Ethnicity in the Early Middle Ages. Turnhout: Brepols, 2002. Pp. 201-218.

Curta, Florin. The Slavic lingua franca: Linguistic Notes of an Archeologist Turned Historian, in East Central Europe. 2004, Vol. 31. No. 1. Pp. 125-148.

Curta, Florin. The Making of the Slavs: Slavic Ethnogenesis Revisited, in Repič, Jaka; Bartulović, Alenka; Sajovec Altshul, Katarina (eds.). MESS and RAMSES II. Mediterranean Ethnological Summer School. Vol. 7. Ljubljana, Znanstvena založba Filozofske fakultete Publ., 2008. Pp. 277-307.

Dostálová, Růžena. Byzantská vzdělanost [Byzantine Education]. Praha, Vyšehrad Publ., 1990. 416 p.

Dvornik, Francis. The Slavs Their Early History and Civilization. Boston, American Academy of Arts and Sciences Publ., 1956. 394 p.

Dzino, Danijel. Becoming Slav, becoming Croat: identity transformations in post-Roman and early medieval Dalmatia. Leiden: Brill, 2010. 272 p.

Ďurina, L’ubomír. Malá knižná reminiscencia [Small book reminiscence], in Proglas. 1999. Vol. 10. No. 2. Pp. 11-14 (in Slovak).

Florya, Boris Nikolaevich. Skazanie o prelozhenii knig na slovenskiy yazyk: Istochniki, vremya i mesto napisaniya [The Tale of the translation of books into the Slavic language: Sources, Date and Place of Composition], in Byzantinoslavica. 1985. Vol. 46. No. 1. Pp. 121-130 (in Russian).

Fried, Johannes. Otton III i Bolestaw Chrobry [Otto III and Boleslas the Brave] / Transl. by Kaźmierczak, Elżbieta; Leder, Witold. Warszawa, Wiedza Powszechna Publ., 2000. 270 p.

Geary, Patrick. Ethnic Identity as a Situational Construct in the Early Middle Ages, in Mitteilungen der anthropologischen Gesellschaft. 1983. Vol. 113. Pp. 15-26.

Geary, Patrick. The Crisis of European Identity Barbarian Ethnicity and Identity in Noble, Thomas F. X. (ed.) From Roman Provinces to Medieval Kingdoms. London; New York: Routledge, 2006. Pp. 27-34.

Geary, Patrick J. Barbarians and ethnicity, in Bowersock, Glen Warren; Brown, Peter; Grabar, Oleg (eds.). Interpreting late antiquity: Essays on the postclassical world. London, Belknap Press, 2001. Pp. 107-129. Graus, František. Raně středověké družiny a jejich význam při vzniku států ve střední Evropě [Early medieval retinues of warriors and its meaning in state building in Central Europe], in Československý časopis historický. 1965. Vol. 13. No. 1. Pp. 1-18 (in Czech).

Homza, Martin. Niekol'ko téz k počiatkom slovenského etnika [Several theses on the origins of the Slovak nation], in Studia Academica Slovaca. 2002. Roč. 31. Pp. 285-295 (in Slovak).

Homza, Martin. Uhorsko-pol’ská kronika: nedocenený prameň k dejinám strednej Európy [Hungarian-Polish chronicle: An unappreciated source to the history of Central Europe]. Bratislava, Post Scriptum Publ., 2009. 223 p. (in Slovak).

Homza, Martin. Stredná Európa I. Na začiatku stredoveku [Central Europe I. At the beginning of the Middle Ages]. Bratislava, Comenius University Publ., 2014. 313 p. (in Slovak).

Homza, Martin. La Grande Moravia tra Oriente e Occidente [Great Moravia Between East and West], in Hrabovec, Emilia; Piatti, Pierantonio; Tolomeo, Rita (eds). I Santi Cirillo e Metodio e la loro eredità religiosa e culturale ponte tra Oriente e Occidente. Raccolta di studi in occasione del $1150^{\circ}$ anniversario della missione dei santi Cirillo e Metodio nella Grande Moravia (863-2013) [Saints Cyril and Methodius and their Religious Heritage and Cultural Bridge between East and West. Collection of studies on the 1150th anniversary of the mission of Saints Cyril and Methodius in the Great Moravia (863-2013)]. Città del Vaticano: Libreria Editrice Vaticana Publ., 2015. Pp. 23-33 (in Italian).

Homza, Martin. Back to the Subject of the Royal Title of Svätopluk I , or Reply to Ján Steinhübel and Other Present and Past AntidicoSvätoplukians, in Slovak Studies. 2016. No. 1-2. Pp. 160-186.

Homza, Martin. Niekol'ko slov k dialógu svätého Konštantína Filozofa s Agarénmi (Saracénmi) a otázke chápania vojny v ňom, in Letková, Alexandra; Lysý, Miroslav; Považan, Michal (eds.). Vojna a vojenstvo 
v práve: Zborník z medzinárodnej vedeckej konferencie, konanej dña 5. 11.2015 v Bratislave. Bratislava, Univerzita Komenského Publ., 2016. Pp. 27-44.

Homza, Martin. 14. marec roku 1074 a jeho dôsledky na vývoj Nitrianskeho kniežatstva, in Letz, Róbert (ed.). Slovenské územie. Martin, Matica slovenská Publ., 2017. Pp. 45-65.

Homza, Martin. Hranice Nitrianskeho vojvodstva (kniežatstva) v pol'ských stredovekých kronikách [Borders of the Nitra Duchy (Principality) in Medieval Polish Chronicles], in Marsina, Richard (ed.). Nitra v slovenských dejinách. Martin, Matica Slovenská Publ., 2002. Pp. 65-78 (in Slovak).

Homza, Martin; et al. Svätopluk v europskom pisomnictve. Študie z dejin svatoplukovskej legendy [Svatopluk in European literature. Studies on the history of the Svatopluk legend]. Bratislava, Post Scriptum Publ., 2013. 749 p. (in Slovak).

Homza, Martin; Rácová, Nad’a. K vývinu slovenskej myšlienky do polovice 18. storočia [On the Development of the Slovak Idea before the mid-18 ${ }^{\text {th }}$ Century]. Bratislava, Stimul Publ., 2010. 275 p. (in Slovak).

Horák Antonín. O Slovanech úlnějinak: Co nebylo o Slovanech dosud známo [On the Slavs in Totally Other Way: What Was not Known About the Slavs to This Day]. Vizovice: LÍPA Publ., 1991. 318 p. (in Czech).

Hromník, Cyril A. Sloveni a Slovensko [Slovaks and Slovakia]. Martin, Matica slovenská, 2015. 928 p. (in Slovak).

Hurbanič, Martin. Posledná vojna antiky: Avarský útok na Konštantínopol roku 626 v historických súvislostiach [Last War of Antiquity: The Avar Siege of Constantinople of 626 in Historical Circumstances]. Prešov, Michal Vlaško Publ., 2009. 377 p. (in Slovak.)

Jones, Siân. The Archaeology of Ethnicity: Constructing identities in the past and present. London, Routledge Publ., 1997. 200 p.

Kohut, Zenon E. From Japheth to Moscow: Narrating Biblical and Ethnic Origins of the Slavs in Polish, Ukrainian, and Russian Historiography (Sixteenth-Eighteenth Centuries), in Journal of Ukrainian Studies. 2008-2009. Vol. 33-34. Pp. 27-292.

Kradin, Nikolay Nikolaevich. Kochevniki Yevrazii [Nomads of Eurasia]. Almaty, Dayk-press Publ., 2007. 416 p. (in Russian).

Králik L'ubor. Stručný etymologický slovnik slovenčiny [Short etymological dictionary of the Slovak language]. Bratislava, VEDA Publ., 2015. 704 p. (in Slovak).

Litvina, Anna Feliksovna; Uspenskiy, Fyodor Borisovich. Vybor imeni u russkikh knyazey X-XVI vv. Dinasticheskaya istoriya skvoz' prizmu antroponimiki [The Choice of the Name of the Russian Princes of the 10th-16th centuries. Dynastic History through the Prism of Anthroponymics]. Moscow, Indrik Publ., 2006. 904 p. (in Russian).

Máčala, Pavol. Etnogeneza Slovanov v archeológii [Ethnogenesis of the Slavs in Archaeology]. Košice, Slovo Publ., 1995. 96 p. (in Slovak).

Malinovská, Nora. Geographical concepts of Sclavinia in historical sources from the sixth to the fourteenth century, with an emphasis on the Moravian-Pannonian and South Slavic tradition, in Homza, Martin; Lukačka, Ján; Budak, Neven; Kucharská, Veronika; Kuzmová, Stanislava; Mesiarkin, Adam (eds.). Slovakia and Croatia. Historical parallels and connections (until 1780). Bratislava; Zagreb: Department of Slovak history, Faculty of Philosophy of the Comenius University, Bratislava; Faculty of Philosophy of Zagreb University, 2013. Pp. 60-65.

Malinovská, Nora. Vývoj koncepcie Sclavinia v 12. storočí a jej reflexia v pol’skej kronike Galla Anonyma [Evolution of the concept of Sclavinia in the $12^{\text {th }}$ century and its reflection in the Chronicle by Gallus Anonimus], in Nové historické rozhl'ady. 2015. Vol. 5. No. 1. Pp. 43-53 (in Slovak).

Mašek, Michal; Sommer, Petr; Žemlička, Josef; et al. Vladislav II.: druhý král z Přemyslova rodu: $k$ 850. výroči jeho korunovace [Vladislav II: The second king from the Přmemslid dynasty: To the $850^{\text {th }}$ anniversary of his coronation]. Praha, Lidové noviny Publ., 2009. 259 p. (in Czech).

Mesiarkin, Adam. Examining the Slavic identity in Middle Ages, in Studia Ceranea. Lodź: Ceraneum. 2013. Vol. 3. Pp. 83-100.

Mesiarkin, Adam. The Basis of Research into Croatian and Slovak Ethnogenesis, in Homza, Martin; Lukačka, Ján; Budak, Neven; Kucharská, Veronika; Kuzmová, Stanislava; Mesiarkin, Adam (eds.). Slovakia and Croatia. Historical parallels and connections (until 1780). Bratislava; Zagreb: Department of Slovak history, Faculty of Philosophy of the Comenius University, Bratislava; Faculty of Philosophy of Zagreb University, 2013. Pp. 38-42.

Mesiarkin, Adam. Veča príspevok k dejinám slovanského práva [Some Notes on the History of the Slovak Law], in Historický časopis. 2016. Vol. 64. No. 2. Pp. 333-360 (in Slovak). 
Montinaro, Federico. Byzantium and the Slavs in the Reign of Justinian: Comparing the Two Recensions of Procopius's Buildings, in Ivanišević, Vujadin; Kazanski, Michel (eds). The Pontic-Danubian Realm in the Period of the Great Migration. Paris; Belgrade: Peeters Publ., 2011. Pp. 89-114.

Plassmann, Alheydis. Origo gentis: Identitäts und Legitimitätsstiftung in früh- und hochmittelalterlichen Herkunfterzählungen [Origo gentis: Identity and Legitimacy Foundation in Early and High Medieval Age Origin Stories]. Berlin, Akademie Publ., 2006. 458 p. (in German).

Podolan, Peter. Aspekty slovenskej historiografie generácie Jána Kollára a Pavla Jozefa Šafárika [Aspects of the Slovak Historiography in the Generation of Ján Kollár anda Pavol Jozef Šafárik], in Forum Historiae. 2007. Vol. 1. Pp. 1-13 (in Slovak).

Podolan, Peter. Odkaz Jána Kollára slovenskej historiografii [Ján Kollár's Behest for the Slovak Historiography], in Historia Nova. Vol. II: Štúdie k jubileu Pavla Jozefa Šafárika. Bratislava, 2011. Vol. 5. Pp. 43-51. Pohl, Walter. Die Awaren: ein Steppenvolk in Mitteleuropa, 567-822 n. Chr. [The Avars: A steppe people in Central Europe, 567-822 A.D.]. München, Beck Publ., 1988. 553 p. (in German).

Pohl, Walter. Telling the difference: Signs of ethnic identity, in Noble, Thomas F. X. (ed.) From Roman Provinces to Medieval Kingdoms. London; New York: Routledge, 2006. Pp. 99-138.

Pohl, Walter. Początki Słowian: Kilka spostrzeżeń historicznych [Origins of the Slavs: Some Historical Notes], in Urbańczyk, Przemysław (ed.). Nie-Stowianie o początkach Stowian. Poznań, Poznańskie Towarzystwo Przyjaciół Nauk Publ., 2006. Pp. 11-27 (in Polish).

Pohl, Walter. Staat und Herrschaft im frühen Mittelalter: Überlegung zum Forschungstand [State and Lordship in the Early Middle Ages: Reflection on the state of research], in Stuart, Airlie; Pohl, Walter; Reimitz, Helmut (eds.). Staat im frühen Mittelalter. Wien, Austrian Academy of Sciences Publ., 2006. Pp. 9-38 (in German).

Pritsak, Omeljan. The Slavs and the Avars, in Settimane di studio del centro italiano di studi sull'alto medioevo. Vol. XXX: Gli Slavi occidentali e meridionali nell'alto medioevo [Week studies of the Italian center for early medieval studies, vol. XXX: Western and Southern Slavs in the early Middle Ages]. Spoleto, Centro di Studio del Centro Italiano di Studi sull' alto Medioevo Publ., 1983. Pp. 353-435.

Smith, David Anthony. Myths and memories of the nation. Oxford: Oxford University Press, 1999. 288 p. Sverdlov, Mikhail Borisovich. K istorii velikomoravskoy kul'turnoy traditsii na Rusi kontsa XI - nachala XII v. [To the history of Great Moravian cultural tradition in Rus' at the end of the $11^{\text {th }}$ and the beginning of the $12^{\text {th }}$ centuries], in Peterburgskiy istoricheskiy zhurnal. 2015. Vol. 7. No. 3. Pp. 10-21 (in Russian).

Timura, Viktor. Zamlčané dejiny: Pôvod a začiatky Slovenov-Slovákov [Concealed History: The origin and beginnings of the Slavs-Slovaks]. Bratislava, Eko-konzult Publ., 2015. 504 p. (in Slovak).

Toporov, Vladimir Nikolaevich. Svyatost' i svyatye v russkoy dukhovnoy kul 'ture. Vol. I: Pervyy vek khristianstva na Rusi [Holiness and saints in Russian spiritual culture. Vol. I: The first century of Christianity in Rus']. Moscow, Yazyki russkoy kul'tury, 1995. 873 p. (in Russian).

Tyszkiewicz, Lech. Koczownicy turecko-mongolscy a migracje Słowian [Turkic-Mongol nomads and Migrations of the Slavs], in Salamon, Maciej; Strzelczyk, Jerzy (eds.). Wedrówka i etnogeneza w staroźytności i w średniowieczu [Migration and Ethnogenesis in the Antiqity and Middle Ages]. Kraków: Historia Iagellonica, 2004. Pp. 190-210 (in Polish).

Urbańczyk, Przemysław. Władza i polityka we wczesnym średniowieczu [Power and Policy in the Early Middle Ages]. Wrocław, Wrocław University Publ., 2000. 280 p. (in Polish).

Urbańczyk, Przemysław. Co się stało w 966 roku? [What happened in 966?]. Poznań, Zysk i S-ka Publ., 2016. 168 p. (in Polish).

Váňa, Zdeněk. Svět dávných Slovanů [World of the Ancient Slavs]. Praha, Artia Publ., 1983. 239 p. (in Czech).

Verešová, Nora. Vývoj chápania geografického termínu Sklavínia v historických prameňoch 6.-14. storočia [Evolution of the notion of the geographical term Sclavinia in the 6th to 14th century sources], in Historicky zbornik. Martin: Matica slovenská, 2008. No. 1. Pp. 124-143 (in Slovak).

Verešová, Nora. Povest' vremennych let a jej koncepcia Slovienskoj zemli [The Tale of Bygone Years and its concept of the slavic land], in Historia Nova. Vol. II: Štúdie k jubileu Pavla Jozefa Šafárika. Bratislava, 2011. Pp. 12-20 (in Slovak).

Wenskus, Reinhard. Stammesbildung und Verfassung. Das Werden der frühmittelalterlichen gentes [Tribal formation and political organization. The making of early medieval gentes]. Köln; Graz: Böhlau Verlag, 1961. 656 p. (in German). 
Wihoda, Martin. První česká království [First Czech kingdom]. Praha, Lidové noviny Publ., 2015. 440 p. (in Czech).

Wolfram, Herwig. Around the Year 1000, in Urbanczyk, Przemysław (ed.). Europa around the Year 1000. Warszawa, DiG Publ., 2001. Pp. 395-399.

Wolfram, Herwig. Origo et religio. Ethnic traditions and literature in early medieval texts, in Noble, Thomas F. X. (ed.) From Roman Provinces to Medieval Kingdoms. London; New York: Routledge, 2006. Pp. 57-74.

Wolfram H. Terminologisches [Terminology], in Ludwig, Uwe; Schilp, Thomas (eds). Nomen und Fraternitas: Festschrift für Dieter Geuenich zum 65. Geburtstag. Berlin; New York, 2008. Pp. 787-802 (in German). Wolfram, Herwig. Conversio Bagoariorum et Carantanorum: Das Weißbuch der Salzburger Kirche über die erfolgreiche Mission in Karantanien und Pannonien mit Zusättzen und Erganzungen [Conversio Bagoariorum et Carantanorum: The White Book of the Salzburg Church on the Successful Mission in Carantania and Pannonia with Additions and Supplements]. Ljubljana, Hermagoras Publ., 2012. 419 p. (in German). 